\title{
INTERSECTIONS OF LAW AND \\ COOPERATIVE GLOBAL CLIMATE GOVERNANCE \\ CHALLENGES IN THE \\ ANTHROPOCENE
}

\author{
Prof Oliver C. Ruppel
}

March 2013 
INTERSECTIONS OF LAW AND COOPERATIVE GLOBAL CLIMATE GOVERNANCE:

CHALLENGES IN THE ANTHROPOCENE

Inaugural lecture delivered on 19 March 2013

Prof Oliver C. Ruppel

Department of Mercantile Law

Faculty of Law

Stellenbosch University

Editor: SU Language Centre

Printing: SUN MeDIA

ISBN: 978-0-7972-1404-0

Copyright (C) Oliver C. Ruppel 


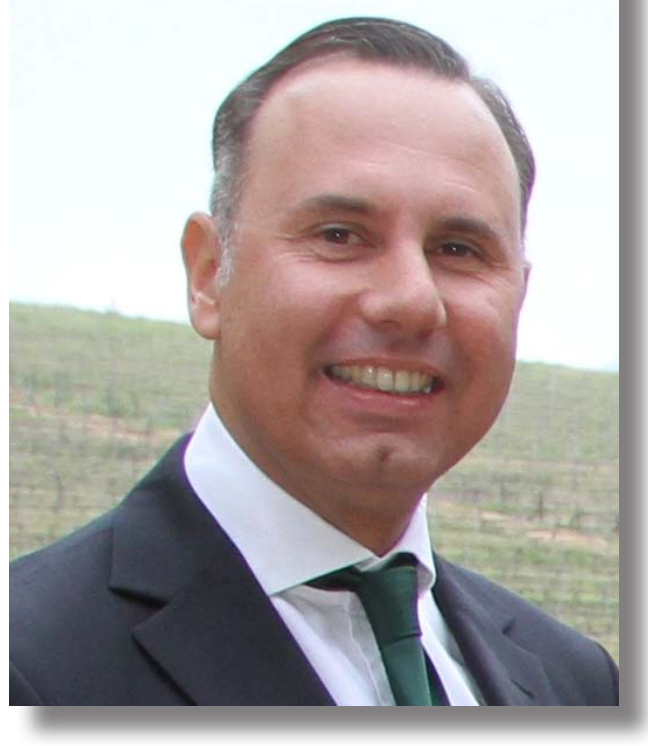

\section{ABOUT THE AUTHOR}

(iver C. Ruppel joined the Department of Mercantile

Law, Stellenbosch University (SU) as professor in January 2011. Until then he held one of the 14 prestigious Chairs in the Academic Programme of the World Trade Organisation (WTO), Geneva (Switzerland), which he established at the Faculty of Law, University of Namibia in 2009. Prior to this, in 2007, he was appointed to serve as Director of the Human Rights and Documentation Centre, a national institute established by statute under the Namibian Ministry of Justice and the University of Namibia.

As the author of seven books, numerous articles in international journals and other academic writings his research focuses on international law and diplomacy, with a particular focus on world trade law, regional integration policy, sustainable development law and environmental law. At SU he is in charge of the LLM modules on aspects of environmental law and legal aspects of world and regional trade. He also lectures as a Professor Extraordinaire at various institutions in Africa and around the world. At present he also serves as AR5 Coordinating Lead Author (CLA) for the Chapter on Africa in the United Nations Intergovernmental Panel on Climate Change (IPCC), Working Group II.

Oliver obtained his undergraduate law degree after studies at the Universities of Lausanne (Switzerland) and Munich (Germany) where he also completed his training as legal practitioner (Freiherr von Schuckmann Attorneys). He holds an LLM (Stell), MM (Hagen), LLD (CU) and a PG Dip Int. Human Rights Law (Finland). He is an International Arbitrator (FA Arb) with the Association of Arbitrators of Southern Africa and a Commercial Mediator (SCCM) with the Swiss Chamber for Commercial Mediation, Zurich (Switzerland). He is a member of the United Nations Environmental Programme's (UNEP) Association of University Lecturers, Nairobi (Kenya); the IUCN Academy of Environmental Law, Ottawa (Canada); the Administrative Law Reform Commission, Ministry of Justice, Windhoek (Namibia); the editorial board of NIELS Journal of Environmental Law, Lagos (Nigeria); the editorial board of Legal Perspectives on Global Challenges Series, The Hague (Netherlands); the editorial board of Law and Constitution in Africa, NOMOS (Germany); the Swiss (SSDI) and the South African (SABILA) Branches of the Association for International Law.

He is married to Dr Katharina Ruppel-Schlichting, who is also a lawyer by profession. They have two daughters, Franziska Freyja Nicolette (10) and Sophia Emma Antoinette (5). 


\section{ACKNOWLEDGEMENTS}

This inaugural lecture is hoped to make a humble contribution in the quest to serve those less fortunate, justice and

peace and the greater glory of God, who is the source of all hope and inspiration. Enormous gratitude goes to my family, particularly to my mother Doris Ruppel, née Transier, and to my wife and colleague Katharina. To my friends, colleagues, students and particularly to my academic mentors who have influenced and supported me on my academic journey: Professors Manfred O. Hinz, Ingo von Muench, Sam K. Amoo, Gerhard Lubbe, David Butler, Ruediger Funiok S.J., Ambassador Dr Bhadra Ranchod and Lord Justice Annel Silungwe. 


\section{INTERSECTIONS OF LAW AND COOPERATIVE GLOBAL CLIMATE GOVERNANCE:}

\section{CHALLENGES IN THE ANTHROPOCENE}

\section{INTRODUCTION}

Ater having once again attended the recent United Nations climate process at the eighteenth Conference of the Parties (COP 18) to the United Nations Framework Convention on Climate Change (UNFCCC) and the eighth Conference of Parties serving as the Meeting of the Parties to the Kyoto Protocol (CMP 8) in Doha, Qatar last December, I wonder what the diplomatic value of such massive negotiations really is. In the last days of the conference, many had already seen the talks close to collapse and were wondering whether COP 18 would need to be reconvened in 2013. Only last-minute decisions lead to a finalisation of the rules for the Kyoto Protocol's second commitment period and agreement on a work programme for the new negotiation track to deliver a new agreement by 2015 .

Unfortunately, climate change is apparently not waiting for the slow timetables of diplomats. The Doha meeting took place at the end of a year (20/2) of increasingly stark warnings both on paper and delivered by Mother Nature herself. The United States suffered from a record drought, foreshadowing the permanent dust bowl the US Midwest is probably going to be turned into by climate change. Hurricane Sandy submerged vast swaths of the US East Coast including New York. Arctic sea ice reached a new record low, 50 per cent below the long-term average. Shortly before the Doha conference the World Bank published a report warning of "cataclysmic consequences" if climate change was not reined in.' And while the Doha conference was underway the Philippines were battered by "Bopha", a typhoon of near-unprecedented strength that caused hundreds of deaths.

The "diagnosis" of planet earth seems rather clear in that constantly growing human and industrial activities have caused dramatically increased emissions of greenhouse gases, which in turn cause the global climate to change rapidly and probably irreversibly. The "symptoms" of climate change are likely to cause more and more natural disasters, extreme weather events and climate induced migration movements. All of these undesirable happenings can be considered as a threat against all aspects of human security with a potential to cause national and cross-boundary conflict and thus endanger global peace and security. The "therapy" against the symptoms of climate change is much less clear and will be discussed in this article. It is argued here that more coherence in the intersections of law and increased cooperative global climate governance should lead the way to cope with the challenges ahead, i.e. the challenges in the Anthropocene.

\section{ANTHROPOCENE - THE AGE OF MAN}

The famous atmospheric chemist and Dutch Nobel Prize winner Paul Crutzen initially coined the term "anthropocene". The term has ancient Greek roots: anthropo meaning "human" and cene meaning "new". In 2000 Crutzen realised that we live in an age primarily shaped by people. From their trawlers scraping the floors of the seas to their dams impounding sediment by the gigatonne, from their stripping of forests to their irrigation of farms, from their mile-deep mines to their melting of glaciers, humans were bringing about an age of planetary change. Crutzen suggested this age be called Anthropocene - "the age of man".2

Mankind has now inhabited or visited almost all places on earth; even set foot on the moon - and the exploration continues. The expansion of mankind, both in numbers and per capita exploitation of the earth's resources, has been astounding. During the past three centuries the world's population increased tenfold to 7 
billion, accompanied e.g. by a growth in cattle population to 1.500 billion. Urbanisation has increased tenfold in the past century. In only a little while we are deemed to exhaust the fossil fuels that were generated over millions of years. Thirty to fifty per cent of the land surface has been transformed by human action, and mankind uses more than half of all accessible fresh water. Considering these and many other major and still growing impacts of human activities on earth and atmosphere, it has become more than appropriate to emphasise the central role of mankind in geology, ecology and law by proposing the term "anthropocene" for the current historical epoch as we already know that the impact of human activities has and will have severe consequences for present and future generations. ${ }^{3}$

For the purpose of this article the human being is seen as the root of the problem, the subject of vulnerability that requires protection, the nucleus of the law and the target of cooperative global climate governance aiming at maintaining peace and security at the same time. The predominant challenges in the Anthropocene, especially in regard of climate change, will be briefly sketched below. Typologically significant of the Anthropocene these challenges must be seen related to the level of complexity, the degree of uncertainty and the novelty that actually surrounds climate change in a process that involves everchanging circumstances that can hardly be fully controlled. As a combination of legal and policy analysis this article shall also examine selected aspects of the framework of international law and governance in the field of climate change.

In 20II, Pope Benedict XVI addressed the German Bundestag illustrating the sources of law in nature and reason by making reference to the popular interest in ecology as a means of respecting nature:

Yet I would like to underline a point that seems to me to be neglected, today as in the past: there is also an ecology of man. Man too has a nature that he must respect and that he cannot manipulate at will. Man is not merely self-creating freedom. Man does not create himself. He is intellect and will, but he is also nature, and his will is rightly ordered if he respects nature, listens to it and accepts himself for who he is, as one who did not create himself. In this way, and in no other, is true human freedom fulfilled.

In 2012, the Club of Rome launched a Report entitled "2052 - A Global Forecast for the Next Forty Years". ${ }^{4}$ In it, author Jorgen Randers tries to answer the question of what our world will look like in forty years' time. Some of the findings include the following:

Humanity is in overshoot (mainly climate-related) and the landing will not be soft [...]. Humanity has a forty- year window to avoid the most serious negative consequences of its decades-long overconsumption splurge. The process of adapting humanity to the planet's limitations may be too slow to stop planetary decline. Global population will grow, peaking at 8 . I billion people in 2042 because of rapid decline in urban fertility. CO2 emissions will peak in 2030, because of a shift toward low-carbon sources of power and heat. Nevertheless, CO2 concentrations will grow, and the global average temperature will pass the danger threshold of $+2 \mathrm{C}$ by 2050 , and peak at $2.8 \mathrm{C}$ in 2080, which could trigger self-reinforcing "runaway" warming with a possible collapse in the second half of the 2 I st century. ${ }^{5}$

Translating the aforementioned statements into the context of the Anthropocene raises the following questions, among others: How many people will the planet be able to support in future? Will runaway climate change take hold? Where will the quality of life improve, and where will it decline? While the process of adapting humanity to the planet's limitations has started, Randers rightfully holds that the "human response could be too slow". ${ }^{\prime}$

\section{I CLIMATE CHANGE AND NATURAL DISASTERS}

Natural disasters are on the increase in the Anthropocene and in this context climate change cannot be viewed in isolation. "Disaster" means a calamitous event or series of events resulting in widespread loss of life, great human suffering or distress, or large-scale material or environmental damage, thereby seriously disrupting the functioning of society? There is wide scientific consensus that the increased number and intensity of climate change induced natural disasters, such as earthquakes, volcano eruptions, tsunamis and hurricanes, is of alarming concern. ${ }^{8}$ Recent incidents include among others the Indian Ocean tsunami (2004), Hurricanes Katrina (2005) and Sandy (2012), Typhoon Bopha in the Philippines (2012), and the earthquakes in Pakistan (2005), Haiti (2010) and Fukushima (20II). The World Bank in a report published in 2012 warned of "cataclysmic consequences" if climate change was not reined in.?

The 2012 Special Report of the Intergovernmental Panel on Climate Change (IPCC) for Managing the Risks of Extreme Events and Disasters to Advance Climate Change Adaptation (SREX) demonstrates shockingly that the severity of the impacts of extreme and non-extreme weather and climate events depends strongly on the level of vulnerability and exposure to these events. Basic risks to which people are subjected by displacement include landlessness, joblessness, homelessness, marginalisation, 
food insecurity, increased morbidity, loss of access to common property resources, and social disarticulation. Particular groups and conditions have been identified as having differential exposure or vulnerability to extreme events; for example race/ethnicity, socioeconomic class and caste, gender, age (both the elderly and children), migration, and housing tenure (whether renter or owner) are among the most common social vulnerability characteristics. 10 "During the period from 1970 to 2008, over $95 \%$ of deaths from natural disasters occurred in developing countries." I

The increase of natural disasters also poses challenges for international law and the international governance framework, especially when it comes to coordination, disaster relief and international cooperation. The international community, even if willing, is not easily able to provide relief to disaster victims. The duty to provide relief is largely incumbent upon the state within whose territory and jurisdiction the disaster occurs. This problem is rooted in the notion of state sovereignty, one of the most defining principles of international law. ${ }^{12}$

An increase in the concentration of greenhouse gases in the atmosphere heightens the possibility that mechanisms that could lead to catastrophic or extreme climate change will be triggered, notwithstanding with the fact that there is uncertainty as to when and how exactly such mechanisms will be triggered. Not reducing GHG emissions, however, means subjecting future generations to the risk of severe harm..$^{13}$ Considering the dangers related to natural disasters and the extremity of the risks involved for future generations, there is in fact no right to presuppose that the effects of climate change will be far from catastrophic. ${ }^{14}$ In other words, "postponing emissions cuts is in some ways like putting a revolver to future people's heads and hoping that there is no bullet in the chamber". ${ }^{5}$ From the point of view of justice, it has been stated that

the nature of [climate change catastrophes] requires us to
take drastic precautions against further [climate change]
that could lead us to pass the tipping points that cause
them. This is the case notwithstanding the fact that we
are in a state of strong uncertainty with respect to these
events; indeed, our strong uncertainty with respect to
them - given their nature - makes the case for action to
prevent them even more persuasive. ${ }^{.6}$

To develop global strategies leading to sustainability of ecosystems against human induced impacts will be one of the greatest tasks of mankind, requiring new and intensive research efforts that will pose many challenges to international law and global governance. Dealing with a global problem like climate change will require a strong legal framework embedded in more effective global institutions in future. International law and global governance traditionally viewed as separate academic disciplines, i.e. law, politics and social sciences - need to become part of a more integrated, coherent, interdisciplinary and holistic interplay, where international law and global governance eventually manage to get a grip on the arguably most significant challenge of our time - climate change.

\subsection{CLIMATE CHANGE AND HUMAN SECURITY}

he protection of the vital core of human lives in
ways that enhance human freedoms and human fulfilment is at the core of the concept of human security. Providing human security means protecting individuals and the community from violent conflicts and from denial of civil liberties and to ensure freedom of expression and belief. It also encompasses the idea of satisfying the basic needs of individuals for food, shelter and clothing. ${ }^{17}$

Climate change has the potential to impose additional pressures on the various aspects of human security. Interrelating issues between climate change and human security include water stress, land use and food security, health security, and environmentally induced migration amongst others. Adverse climate events not only deepen poverty vulnerability in developing countries, ${ }^{18}$ they impact on all aspects of human security, either directly or indirectly. The impacts of climate change on the agricultural sector are probably of most direct and profound nature. Impacts of climate change, droughts and floods in particular, will have an impact on food availability, food access and nutrient access. ${ }^{19}$

The ultimate damages of climate change may significantly affect economic growth. ${ }^{20}$ Climate extremes exert substantial stress on low-income populations in particular. The poor are most vulnerable to multiple dimensions of climate change such as heat waves, sea level rise, the destruction of coastal zones and water shortages due to drought. ${ }^{21}$ Health security is another important aspect of human security endangered by the impacts of climate change and the effects on health will exacerbate inequities between rich and poor. ${ }^{22}$ Africa is particularly vulnerable in this regard as threats to health security are usually greater for poor people in rural areas, particularly children, due to malnutrition and insufficient access to health services, clean water and other basic necessities. Major killer diseases such as malaria expand their coverage as a result of global warming. Global and regional climatic variability enhances the risk of a further spread of other infectious diseases such cholera, ${ }^{23}$ dengue fever, ${ }^{24}$ and meningitis. ${ }^{25}$ 


\subsection{CLIMATE CHANGE, CONFLICT AND MIGRATION}

$T^{\text {The }}$ he impacts of climate change on violent conflicts and changing migration patterns are further aspects related to the aforementioned concept of human security, and again with particular relevance on the African continent. While violent conflict can be seen as a driver of vulnerability to climate change, migration is a stressor that increases vulnerability to climate change. The linkage between climate related environmental variability and conflict has attracted much attention and debate. ${ }^{26}$ Yet, in 2011 Achim Steiner, Executive Director of the United Nations Environment Programme (UNEP), asserted that climate change is a "threat multiplier" that has fundamental implications for weather, settlements, infrastructure, food insecurity, livelihoods and development. Competition over scarce water and land, exacerbated by regional changes in climate, was already a key factor in local conflicts in Darfur, the Central African Republic, northern Kenya and Chad. ${ }^{27}$

Climate induced migration ${ }^{28}$ is an aspect closely related to the concept of human security. ${ }^{29}$ Notwithstanding the fact that there is no certainty as to what exactly climate change will mean for migration patterns, there seems to be consensus that climate change will over time lead to population movements. Migration can be an adaptation strategy and can enhance adaptive capacity ${ }^{30}$ People migrate either temporarily or permanently, within their country or across borders, and many have an environmental signal in their reason for migration. The African continent ${ }^{31}$ and small island nations around the globe are most likely to be among those who will produce the most climate migrants in future. The total number of displaced people in Africa increased from 697,066 in 2008 to 1,7 million in 2010.32

The causes for displacement and migration are manifold; however, climate change is one of the interlinking issues. Potential drivers of migration are push and pull factors related to the region or country of origin or destination respectively, and intervening factors that facilitate or restrict migration, all of which may interact in different ways. $^{33}$ The available evidence suggests that, globally, the large majority of people displaced by disasters caused by sudden-onset hazards (hurricanes, floods, earthquakes, etc.) remain temporarily and internally displaced with people returning home to rebuild their homes and lives. ${ }^{34}$ This might be different in the case of slow-onset disasters such as droughts and sea level rise with increasing crossborder movement of a permanent nature. ${ }^{35}$

\section{INTERSECTIONS OF LAW}

The aforementioned scenarios have surely attracted the reader's concern. In order to address this concern, it is necessary to call for effective regulation in order to prevent the worst case. In this context the law comes in: "Law is the major instrument by which mature societies consolidate their internal and external relationships" and "without legal rules, the life of a society becomes unpredictable and aleatory." ${ }^{36}$ For good reason, there is no clearly defined term, nor a marked branch of the law, which would cover all legal implications of climate change. Subsummising climate change under any legal structure is a challenging task due to the endless ramifications of climate change and particularly due to the interdisciplinary nature of climate change and its impacts on various segments of our planet. Climate change can therefore only be tackled through a combination of political, legal and natural science tools. Climate change, biodiversity loss, the marine environment, ozone depletion, genetic resources, intellectual property issues, international trade and human rights - among others - are strongly interrelated. There are numerous intersections of law that occur when climate change is looked at from a legal perspective. Efforts to curb climate change have given rise to the evolution of some new principles and concepts of international law, including among others the principle of common but differentiated responsibilities, the notion of common concern of humankind and the need for protection of the most vulnerable. ${ }^{37}$

Climate change permeates the law in many ways, creating intersections of law in its diverse fields. If one would brand a new discipline "climate change law", this would be both international and domestic in nature and include (at least) two complementary dimensions: procedural and substantive.

The procedural dimension is related to the right to information, the right to participate in decision-making, and the right of access to justice. Climate change opens a multitude of challenges of a procedural nature. To what extent these challenges are relevant depends on the following aspects, among others: The question of whether and under what conditions an individual, organisation or state has the right to commence action needs to be addressed. The issue of locus standi is of great relevance in respect of judicial enforcement, which still needs specific attention. So far public interest litigation is scarce. Yet it seems to be most suitable in the context of climate change. Another focal point deals with the question of who would be the proper addressee of claims relating to climate change damages, and whether a right to environment is to be enforced vertically between individuals and/or horizontally between individuals and states. Moreover, the 
question of enforcement at the national or international level is of particular interest in the globalising world, where the climate knows no boundaries. In the IC judgment in the so-called Pulp Mills case the Court for instance held as follows: ${ }^{38}$

[T]here are situations in which the parties' intent upon conclusion of the treaty was, or may be presumed to have been, to give the terms used - or some of them - a meaning or content capable of evolving, not one fixed once and for all, so as to make allowance for, among other things, developments in international law.

The substantive dimension of climate change law is far reaching and incorporates among others constitutional law, administrative law, environmental law, water law, criminal law, the law of nuisance, the law of delict, insurance law and even tax law. On a vertical level, intersections of law occur on a very broad scale of the different but interrelated branches of the law with the underlying assumption that climate change law consists of the sum of legal provisions protecting the climate itself and those that protect the climate from the negative effects of climate change. This scale ranges from environmental law (with its multiple sub-branches such as biodiversity law, environmentally relevant provisions within the law of the sea, outer space law, energy and mining law, and specific legal instruments relating to climate change, etc.) to human rights law, humanitarian law, trade and investment law, the law on the use of force, criminal law, and liability law among others. ${ }^{39}$

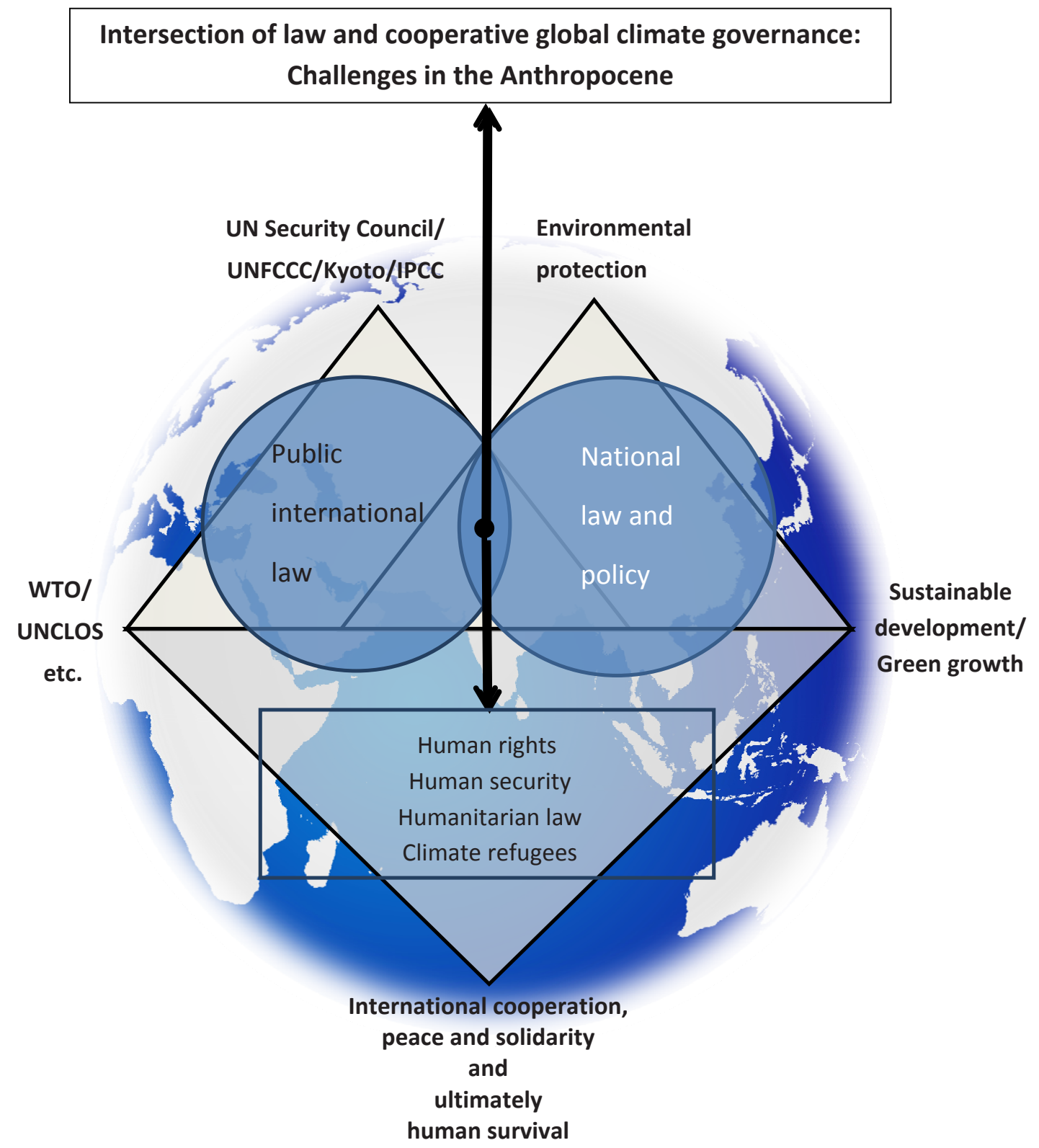

CC Oliver C. Ruppel; designed by Cord Lüdemann 
On a horizontal level, climate change law intersections can be found at the different levels of international and national law. The horizontal level entails international law ${ }^{40}$ with multilateral agreements on the global, regional and sub-regional level, bilateral (and unilateral) agreements, general principles of law, customary international law, case law, and other instruments such as declarations, agendas among others. National law may consist of constitutional law, statutory law, common law, case law, customary law, policies, strategies and action plans and other relevant instruments. Climate related

policies are for instance central to the development of sustainable energy generation and markets. Laws governing sustainable energy development and supply cut across many sectors such as mining, forestry, agriculture, environment, water, industry, electricity, and petroleum, and hence require coordination - a complex challenge that is not easily overcome. ${ }^{41}$

Intersections not only occur with regard to the question whether it is national or international law that applies, or both, but also within the categories of national or international law themselves. A further problem is the demarcation between 'hard' and 'soft' law. Some of the sources of national and international law are obligatory; others are of a non-binding nature. In the climate change context, the lack of globally applicable enforceable legal obligations is without doubt one of the major deficiencies ${ }^{42}$ and one of the major subjects of and challenges for current climate change negotiations.

Furthermore, there has been an emergence of global administrative law forming trans-governmental regulation and administration in such fields as:

security, the conditions on development and financial assistance, environmental protection, banking and financial regulation, law enforcement, telecommunications, trade in products and services, intellectual property, labour standards, and cross-border movement of populations, including refugees. Increasingly, these consequences cannot be addressed effectively by isolated national regulatory and administrative measures. ${ }^{43}$

Summarising it can be stated that cross-cutting themes thus include, among others, the relationship between international environmental law and general principles of international law; conflicts among differing legal regimes; the range of approaches to the regulation of activities within and beyond areas under national jurisdiction; the role and impact of competing state interests in the negotiation and enforcement of international regimes; the challenge of regulating in the face of scientific uncertainty; the role of both 'soft' and 'hard' law in addressing the global problem; and the potential contribution of the judiciary and international tribunals in the further development of climate change law.

The intersections of international climate change law and multiple overlapping regulatory bodies reflect the fragmentation of global climate change governance in the absence of a universal climate change regime. This makes international climate change law extremely complex and global climate governance not very orchestrated. This overlapping complexity in the different climate change (related) regimes can be observed in various United Nations conventions, the international human rights regime, the world trade order (WTO), multilateral environmental agreements (MEAs) and other international legal instruments that (directly or indirectly) deal with climate change, such as the Vienna Convention on Ozone Depletion, the Montreal Protocol, ${ }^{44}$ the Convention on Biodiversity, the London Dumping Convention, the Convention on International Trade in Endangered Species of Wild Fauna and Flora (CITES), the RAMSAR Convention on Wetlands of International Importance and the Convention on the Conservation of Migratory Species of Wild Animals, among others. Same applies for geo-engineering, nuclear technology, intellectual property, international investment and finance regimes. ${ }^{45}$

For the purpose of this article, the following sections shall only reflect on the climate regimes around the United Nations Framework Convention on Climate Change (UNFCCC), the work of the Intergovernmental Panel on Climate Change (IPCC), the role of the United Nations Security Council, the international human rights regime, international refugee law, the law of the sea regime (UNCLOS) and the world trade order (WTO).

\section{I THE UN FRAMEWORK CONVENTION ON CLIMATE CHANGE ANDTHE KYOTO PROTOCOL ${ }^{46}$}

The international legal climate change regime is a product of international law, which has developed rapidly over the past few decades, especially since the dawn of the United Nations (UN), when rules and norms 
regulating activities carried on outside the legal boundaries of nations were developed. Numerous international agreements - bilateral, regional or multilateral - have been concluded and international customary rules, as evidence of a general practice accepted as law, have been established. International agreements are binding upon states if the consent to be a party to them is expressed by a signature followed by ratification, or by accession, where the state is not a signatory to a treaty, or by declaration of succession to a treaty concluded before such a state existed. The sources of international law in general are listed in Article 38 of the Statute of the International Court of Justice (ICJ), the principal judicial organ of the United Nations. However, considering that Article 38 of the Statute of the ICJ was first drafted in 1920, these provisions no longer reflect all the sources of today's international law. New developments in respect of sources of law have to be considered in addition to those recognised in Article 38.

The 1992 United Nations Conference on Environment and Development (UNCED) in Rio de Janeiro, Brazil, reaffirmed the Declaration of the United Nations Conference on the Human Environment, adopted in Stockholm, Sweden, in 1972, seeking to build upon it with the goal of establishing a new and equitable global order through the creation of new levels of cooperation among states, key sectors of societies and people, working towards international agreements which respect the interests of all and protect the integrity of the global environmental and developmental system, recognising the integral and interdependent nature of the earth. It proclaims first and foremost that human beings are at the centre of concerns over sustainable development. They are entitled to a healthy and productive life in harmony with nature (Principle 1). Moreover, states have, in accordance with the Charter of the United Nations and the principles of international law, the sovereign right to exploit their own resources pursuant to their own environmental and developmental policies, and the responsibility to ensure that activities within their jurisdiction or control do not cause damage to the environment of other states or of areas beyond the limits of national jurisdiction (Principle 2). Thirdly, the right to development must be fulfilled so as to equitably meet developmental and environmental needs of present and future generations (Principle 3).

The United Nations Framework Convention on Climate Change (UNFCCC) and the Kyoto Protocol are 'treaties' in terms of international law and Article 2.I (a) of the Vienna Convention on the Law of Treaties. International oversight and implementation of the climate regimes are only possible through an array of institutions under the UNFCCC and Kyoto regimes. ${ }^{47}$ The Conference of Parties (COP) is the supreme body of UNFCCC, which regularly reviews the implementation of the Convention and any related legal instruments that the COP may adopt to promote the effective implementation of the Convention.

The mandate of the COP to amend the UNFCCC and the Kyoto Protocol, or adopt a new legal instrument that either supplements or replaces the Kyoto Protocol, is broadly limited by the UNFCCC's objective and guiding principles. The UNFCCC, however, only provides a general framework to combat climate change. Parties have a responsibility to protect the climate system in accordance with their common but differentiated responsibilities and respective capabilities. ${ }^{48}$

The UNFCCC allows for the introduction of protocols to the Convention. The first of these is the Kyoto Protocol. This agreement came into force on 16 February 2005. A number of global initiatives are being implemented to assist in the operationalisation of the UNFCCC. For example, the Global Environment Facility (GEF) serves as an operating entity of the UNFCCC financial mechanism and has been supporting the national capacity self-assessment process at national level for some time. This is aimed at providing countries with an opportunity to articulate their own capacity needs in implementing the UNFCCC, the other two Rio Conventions and other non-Rio Conventions (e.g. chemicals). The ultimate objective of the UNFCCC is to stabilise greenhouse gas concentrations "at a level that would prevent dangerous anthropogenic interference with the climate". ${ }^{49}$ Such a level - and this is generally regarded by developing countries as an integral part of the aforementioned objective - should be reached within a timeframe, which allows ecosystems to adapt naturally to climate change while guaranteeing that food production is not at risk and that development occurs in a sustainable manner.

The Convention is a framework document, identifying two major areas of action required to address climate change, namely mitigation ${ }^{50}$ and adaptation. ${ }^{51}$ Moreover, the Convention as a legal instrument identifies a wide range of measures (see, e.g., the diversity of measures in Article 4.I) to address climate change through other activities such as scientific and technical cooperation, technology transfer, finance etc. The UNFCCC allows any state to become a party, and as at 2011 has 194 signatories, making it a global instrument. Within this framework of global participation, actual obligations of parties differ substantially between industrialised and developing countries. The UNFCCC enshrines a number of key principles (Article 3) including the principles of "equity" and "common but differentiated responsibilities and respective capabilities". Today's accumulated greenhouse gas emissions originate mainly from over 150 years of carbon-based industrial activity in developed 
states. Therefore UNFCCC recognises that all countries have a common responsibility to tackle climate change, but places a heavier burden on industrialised states to fulfil their historic responsibility of addressing climate change. ${ }^{52}$

These principles are reflected in the obligations established for developed and developing countries in the Convention, including those relating to mitigation, adaptation, technology transfer, finance as well as communication of information relating to the Convention. The Convention goes further to make provision for countries in special situations, including particularly vulnerable countries, least-developed countries and countries undergoing transition to a market economy. Article 4(4) UNFCCC, for instance, states:

The developed country parties [...] shall assist the developing country parties that are particularly vulnerable to the adverse effects of climate change in meeting costs of adaptation to those adverse effects.

The Kyoto Protocol came into force in 2005 and shares the objectives and the institutions of the UNFCCC. The major distinction between the two is that while the UNFCCC only encourages industrialised countries to stabilise greenhouse gas emissions, the Kyoto Protocol obliges them to do so. Just like the UNFCCC, the Kyoto Protocol imposes a heavier burden on developed nations under the principle of 'common but differentiated responsibilities'. This group of countries must first and foremost take domestic action to address climate change, but the Kyoto Protocol allows them a certain degree of flexibility in satisfying their emissions commitments.

Under the Kyoto Protocol, actual emissions have to be monitored - each party must keep a national register to show measures carried out under the Kyoto Protocol instruments. The secretariat keeps an independent transaction log to verify that operations are consistent with the rules of the Kyoto Protocol. The most important aspect of the Kyoto Protocol is arguably the creation of an aggregate target for the developed countries (Article 3) as well as legally binding and quantified individual targets set out in Annex B. It should also be noted that there are significant commitments for reporting, review, independent assessment and compliance (Articles 5, 7, 8 and 18 ).

Under the adaptation objective, the Kyoto Protocol, like the UNFCCC, is designed to support countries in adapting to the inevitable effects of climate change and to facilitate the development of techniques that can help increase resilience to climate change impacts. An Adaptation Fund was set up to help with concrete adaptation projects in developing countries. The Adaptation Fund is a 'solidarity fund' in which a proportion of the revenue of CDM projects in developing countries is contributed to a fund to assist adaptation projects in other developing countries.

In the course of the United Nations Climate Change Conference held in Cancun, Mexico in 2010, a set of agreements were reached, building on the Bali Road $\mathrm{Map}^{53}$ and the Copenhagen Accord, ${ }^{54}$ which clearly reflect that the parties to the UNFCCC and the Kyoto Protocol had taken up the issue of climate justice. Three decisions have resulted from the Cancun Conference: one decision by the COP to the UNFCCC ${ }^{55}$ and two decisions by the COP serving as the meeting of the Parties to the Kyoto Protocol. ${ }^{56}$ The reduction of greenhouse gas emissions and the support for developing nations to deal with climate change are at the core of the Cancun agreements. In order to advance action regarding the aim of the reduction of greenhouse gas emissions in a mutually accountable way, national plans are formally captured at international level under the banner of the United Nations Framework Convention on Climate Change. Support for developing nations is provided for in the Cancun agreements and includes financial, technology and capacity-building support, which is to be realised through various mechanisms: nationally appropriate mitigation actions (NAMA); reducing emissions from deforestation and forest degradation (REDD+); the Clean Development Mechanism (CDM); the Cancun Adaptation Framework (CAF); the technology mechanism; and the Green Climate Fund (GCF).

At the 18th Conference of the Parties (COP I8) to the UNFCCC and the 8th Session of the COP serving as the Meeting of the Parties (MOP 8) to the Kyoto Protocol held in Doha, Qatar in 2012, a second commitment period under the Kyoto Protocol has been launched, with 2020 as the end date. Unfortunately, several countries that had previously participated in the Kyoto Protocol have not joined the second commitment period, such as Russia, Canada, New Zealand and Japan. Although it had been agreed to work towards a universal climate change agreement covering all countries from 2020 it will still be seen whether such agreement is to be adopted by $20 \mathrm{I} 5$.

\subsection{THE INTERGOVERNMENTAL PANEL ON CLIMATE CHANGE (IPCC)}

The Intergovernmental Panel on Climate Change (IPCC) was established by the United Nations Environment Programme (UNEP) and the World Meteorological Organisation (WMO) in 1988. The ultimate role of the IPCC is:

to assess on a comprehensive, objective, open and transparent basis the scientific, technical and socio-economic information relevant to understanding the scientific basis of risk of human-induced climate change, its potential impacts and options for adaptation and mitigation. Review 
by experts and governments is an essential part of the IPCC process. The Panel does not conduct new research, monitor climate-related data or recommend policies. It is open to all member countries of WMO and UNEP. ${ }^{57}$

In the UNFCCC explicit reference is made to the IPCC under Article 21:

[T] he head of the interim secretariat referred to in paragraph I above will cooperate closely with the Intergovernmental Panel on Climate Change to ensure that the Panel can respond to the need for objective scientific and technical advice.

The IPCC was subsequently and repeatedly included in the Kyoto Protocol to the Convention where the methodological work of the Intergovernmental Panel on Climate Change should be taken into account in formulating guidelines on verification of emission reductions..$^{58}$

The IPCC consists of three Working Groups: The IPCC Working Group I (WG I) assesses the physical scientific aspects of the climate system and climate change. The main topics assessed by WG I include: changes in greenhouse gases and aerosols in the atmosphere; observed changes in air, land and ocean temperatures, rainfall, glaciers and ice sheets, oceans and sea level; historical and paleoclimatic perspectives on climate change; biogeochemistry, carbon cycle, gases and aerosols; satellite and other data; climate models; climate projections, causes and attribution of climate change. ${ }^{59}$ The WG I Technical Support Unit, which manages the organisational and administrative activities of the Working Group, is hosted by the University of Berne, Switzerland, and funded by the government of Switzerland. ${ }^{60}$

The IPCC Working Group II (WG II) assesses the vulnerability of socio-economic and natural systems to climate change, negative and positive consequences of climate change, and options for adapting to it. It also considers the relationship between vulnerability, adaptation and sustainable development. Information is evaluated by sector (water resources; ecosystems; food and forests; coastal systems; industry; human health) and region (Africa; Asia; Australia and New Zealand; Europe; Latin America; North America; Polar Regions; Small Islands). ${ }^{61}$ In its reports, Working Group II elaborates on the scientific, technical, environmental, economic and social aspects of the vulnerability (sensitivity and adaptability) to climate change of, and the negative and positive consequences for, ecological systems, socioeconomic sectors and human health, with an emphasis on regional, sectoral and cross-sectoral issues. The WG \| Technical Support Unit is housed at the Carnegie Institution for Science in Stanford, California, USA. ${ }^{62}$
The IPCC Working Group III (WG III) assesses options for mitigating climate change through limiting or preventing greenhouse gas emissions and enhancing activities that remove them from the atmosphere. The main economic sectors are taken into account, both in a short-term and in a long-term perspective. The sectors include energy, transport, buildings, industry, agriculture, forestry, and waste management. WG III analyses the costs and benefits of the different approaches to mitigation, considering also the available instruments and policy measures. The approach is more and more solution oriented. ${ }^{63}$ The IPCC WG III Technical Support Unit is housed at the Potsdam Institute for Climate Impact Research in Potsdam, Germany. ${ }^{64}$

The above three working groups were intended to:

draw on slightly different scientific constituencies, since impact and responses would require factoring in research outside the physical sciences and would touch on political issues. Working Group I would be dominated by climate scientists, while Working Groups II and III would have a wider participation, including, as time went on, by economists and other social scientists. ${ }^{65}$

\section{The historical}

roots of IPCC's strength reached very deep. Most people were scarcely aware that IPCC, and virtually every other international initiative [...], relied on a key historical development: The worldwide advance of democracy. It is too easy to overlook the obvious fact that international organizations govern themselves in a republican fashion, with vigorous free debate among all members and votes in councils of elite leaders. ${ }^{66}$

Often, as in IPCC, decisions among the dozens or hundreds of elite leaders are made by a negotiated consensus in a spirit of equality, of mutual accommodation, and of commitment to the community process - all of which are seldom celebrated, but essential, components of the republican political culture. ${ }^{67}$ It has been said that it is

an important historical fact that such international regimes have been created chiefly by governments that felt comfortable with such mechanisms at home, that is, democratic governments. Nations like Nazi Germany, Communist China, and the former SU did little to create international organizations (aside from front groups under their own thumb), and often participated in them awkwardly. Happily, in the second half of the twentieth century, nations under democratic governance became globally predominant. ${ }^{68}$ 
That encouraged the proliferation of international institutions that were democratic, or at any rate elitebased republican, exerting an ever stronger influence in world affairs. ${ }^{69}$ "The democratization of international relationships was the foundation upon which IPCC took its stand."70 In 2007, the IPCC and Albert Arnold (Al) Gore Jr. were awarded the Nobel Peace Prize "for their efforts to build up and disseminate greater knowledge about manmade climate change and to lay the foundations for the measures that are needed to counteract such change".?1

This Prize was most probably not awarded to the IPCC without good reason. ${ }^{72}$ Despite criticism it should not be forgotten that the IPCC is a very valuable institution that tries to help in an unprecedented way to resolve socio-political conflicts by gathering scientific knowledge and presenting it in a comprehensible manner. "The evidence shows the scientific consensus arrived at by the Intergovernmental Panel on Climate Change (IPCC) is a solid one, given the composition of the panel, and an innovative means of connecting science with politics."73

The 4th IPCC Assessment Report (AR4) - against all contrary opinions - can be considered a reliable study on the state of climate science and uncertainties in the year 2007. Although two minor mistakes had been detected in the report of several thousand pages, the rest remains valid. ${ }^{74}$ The 5th IPCC Assessment Report (AR5) is expected to be published in 2014. ${ }^{75}$ For AR5 the IPCC has made it a priority to engage developing countries more fully:

\begin{abstract}
AR5 will be able to provide much greater regional detail than available literature has allowed in the past. We all have to make a major effort to do full justice to expectations in different parts of the world, and for this reason $[\ldots]$ we must take care of this aspect as diligently as possible. We would need to be equally diligent in going the extra mile in assessing literature in local languages where for scientific reasons we would be able to enrich the AR5 with comprehensive knowledge and information. ${ }^{76}$
\end{abstract}

The IPCC gives valuable advice to national governments and international organisations. ${ }^{77} \quad$ By effectively and objectively assessing scientific knowledge and prevailing uncertainty, the IPCC provides the world with the best possible and much-needed evidence of climate change related impacts. Scientific authority also depends on reliable indicators. ${ }^{78}$ In this context the IPCC plays - no doubt - a decisive role in the policy reform and political decision-making process.

Because of its scientific and intergovernmental nature, the IPCC embodies a unique opportunity to provide rigorous and balanced scientific information to decision makers. By endorsing the IPCC reports, governments acknowledge the authority of their scientific content. The work of the organization is therefore policy-relevant and yet policyneutral, never policy-prescriptive. ${ }^{79}$

The IPCC thus bridges the two fields, by getting the facts right so the policies may be effective. In effect, "if scientists cannot agree, political leaders and other stakeholders are unlikely to agree either." 80

\subsection{THE UN SECURITY COUNCIL AND THE RESPONSIBILITYTO PROTECT}

nly recently UN Secretary-General Ban Ki-moon
made reference "to the gathering threat of climate change" at the Sorensen Distinguished Lecture on the United Nations at the Council on Foreign Relations. He said:

[S]cientists have long sounded the alarm. Top-ranking military commanders and security experts have now joined the chorus. Yet the political class seems far behind [...]. Too many leaders seem content to keep climate change at arm's length, and in its policy silo. Too few grasp the need to bring the threat to the centre of global security. ${ }^{81}$

\section{Framing climate change more and more}

as a security issue could serve to enhance and broaden the policy response at various governance levels by facilitating policy makers and their publics recognizing the common origins of what may otherwise appear as unconnected phenomena. Debate about climate change is often couched in terms of a hypothetical future: by how much the temperature will rise, by how much countries should reduce their emissions, and the nightmare scenarios that may come into play if they fail to do so. ${ }^{82}$

This focus on what may appear a hypothetical future renders climate change a particularly daunting and difficult policy arena for governments because, as NATO Secretary General Anders Fogh Rasmussen explained:

The science is not yet perfect. The effects are just starting to be visible, but it's difficult to pin down what's actually changing because of climate change. The timelines are not clear either. And as a politician, I know exactly what that means. When we have to choose between spending money now on schools or health care, or diverting funds to try to prevent something that will likely only hurt long after they have left office, the choice for most leaders is pretty clear. And, let me say, not hard to understand. ${ }^{83}$

In 201 I, the United Nations Security Council expressed concern that the possible adverse effects of climate change could, in the long run, aggravate certain existing threats to international peace and security and that the loss of territory in some states could have possible security implications. ${ }^{84}$ In a statement read out by the then 
Council President, Peter Wittig of Germany, following a day-long debate on "maintenance of international peace and security: the impact of climate change", he noted that "conflict analysis and contextual information" on, among others, the "possible security implications of climate change" was important when climate issues drove conflict, challenged implementation of Council mandates or endangered peace processes. ${ }^{85}$

UN Secretary-General Ban Ki-moon, who opened the aforementioned 201 I Council debate, pointed to the devastating impact of extreme weather and rising seas on lives, infrastructure and budgets - an "unholy brew" that could create dangerous security vacuums. "We must make no mistake. [...] The facts are clear: climate change is real and accelerating in a dangerous manner," he said, declaring that it "not only exacerbates threats to international peace and security; it is a threat to international peace and security". Events in Pakistan, the Pacific islands, Western Europe, China and the Horn of Africa, among other areas, illustrated the urgency of the situation, he said. Worldwide, hundreds of millions of people were in danger of food and water shortages. Environmental refugees were "reshaping the human geography" of the planet. ${ }^{86}$

Although the aforementioned statements clearly frame climate change as a potential source of conflict, a potential threat to national and international peace and human security, the future role of the UN Security Council with regard to climate change remains to be determined. The Council would arguably be acting within its legal powers if, for example, it passed resolutions requiring governments at all levels "to prioritize adaptation strategies in their planning and national governments to contribute military or other resources to a global disaster mitigation unit". ${ }^{87}$ Yet in 20 I I, as in 2007, the Security Council did not take a decision on climate change. This time, however, it did agree on a presidential statement, a non-legally binding document adopted by consensus, expressing concern that possible adverse effects of climate change may, in the long run, aggravate certain existing threats to international peace and security. ${ }^{88}$

At present, the UN Security Council has only 15 members - five of which are permanent and ten of which are members for two-year terms. Decisions on all but procedural matters are taken by an affirmative vote of nine members, including the concurring votes of the five permanent members. ${ }^{89}$ A cornerstone of the United Nations Charter paradigm is the notion of collective security which is perhaps the first and most obvious manifestation of the principle of solidarity in the post World War II era. ${ }^{90}$ In fact, it forms the political and legal foundation for the collective security system established by the UN Charter. Under Article 25 of the UN Charter, member states "agree to accept and carry out the decisions of the Security Council". 91 Article 39 stipulates that the Security Council can identify a "threat to the peace, breach of the peace, or act of aggression" and "make recommendations, or decide what measures shall be taken in accordance with
Articles 41 and 42, to maintain or restore international peace and security". ${ }^{92}$ Article 41 provides for the Council to decide on appropriate measures not involving the use of armed force, ${ }^{93}$ and Article 42 provides that if the Security Council considers that such measures "would be inadequate or have proved to be inadequate, it may take such action by air, sea, or land forces as may be necessary to maintain or restore international peace and security".94 The Security Council can thus enforce its decisions made in response to a perceived "threat to the peace, breach of the peace, or act of aggression" by use of force if it deems it necessary to do so. It is generally accepted among the international law community that it is at the Council's political discretion to define what constitutes a threat to the peace for the purposes of Chapter VII of the UN Charter. ${ }^{95}$

A still controversial manifestation of the notion of solidarity in international law is the emerging doctrine of the responsibility to protect. This concept was developed by the International Commission on Intervention and State Sovereignty in September 2000, after the UN Secretary General Kofi Annan emphasised the grave failure of the international community to handle gross and systematic violations of human rights such as those perpetrated in Rwanda and other areas. ${ }^{96}$ The aforementioned concept has gained growing attention in the context of the notion of global solidarity and collective security as it aims to address legal and political dilemmas for intervention to stop or pre-empt human suffering and crimes against humanity. ${ }^{97}$

Under Article 52 of the UN Charter, regional organisations may undertake actions aimed at the maintenance of international peace and security. Article 53 (I) of the UN Charter specifically provides that such regional organisations may undertake enforcement measures, provided that they have the authorisation of the UN Security Council. Most obviously the crux of the responsibility to protect concept is the dilemma of state sovereignty and intervention for humanity. In light of this, current discussions focus on the duty of the international community and the territorial state in cases of natural disasters, raising the question whether the doctrine of the responsibility to protect can actually be extended to the international law relating to disaster relief and in particular to cases of grave circumstances such as severe human suffering during times of natural disasters. Unfortunately, so far for international law and politics it still seems to make a big difference whether human suffering is the result of a natural disaster or of an (international) armed conflict.9 However, when responding to the question whether the doctrine of the responsibility to protect should in future be extended to the international law relating to disaster relief one could argue with Achim Steiner as follows:

There is no reason why the international community cannot avoid escalating conflicts, tensions and insecurity related to a changing climate if a deliberate, focused and collective response can be catalyzed that tackles the root 
causes, scale, potential volatility and velocity of the challenges emerging. In bringing forward a response that enhances global security and cooperation on the climate challenge, the world can perhaps also better manage risk from numerous other challenges and in doing so diminish tensions between nations and lay the foundations and possibilities of a more sustainable and equitable peace. ${ }^{99}$

It becomes apparent from the above that climate change is moving from mere politicisation towards a state of securitisation. ${ }^{100}$ Once an issue is successfully securitised it moves out of the sphere of normal politics to be dealt with as an emergency issue without the normal democratic processes being brought to bear, and the securitising actor can, through this process, infuse the concept of 'security' with any meaning desired. ${ }^{101}$ Full securitisation would seem to be represented by the issue moving outside of the normal multilateral treaty framework used to manage political issues of mutual concern to the body with "primary responsibility for the maintenance of international peace and security": the United Nations Security Council. ${ }^{102}$

Most obviously, the nature and "impacts of climate change challenge traditional notions in international law, most notably those relating to the principle of territorial sovereignty, with its presumptions of defined territory and fixed maritime boundaries". 03 "Sovereignty in the relations between States signifies independence. Independence in regard to a portion of the globe is the right to exercise therein, to the exclusion of any other State, ${ }^{104}$ the functions of a State." The world is divided into clearly demarcated territories. Each territory has one government within the territory, with full jurisdiction over all persons and resources within its domain. ${ }^{105}$ In the context of climate change it seems appropriate, however, to explore whether the law of state responsibility offers a useful paradigm to address the problem. ${ }^{106}$ Unfortunately, however, national governments and statesmen more often than not regard themselves as

primarily responsible not vis-a-vis an existing global order, which they all too often violate, but vis-a-vis a possible future order, which they lack the will and vision to help bring about. This is the ultimate crime against peace and justice. $^{107}$

The UNFCCC and the subsequent Kyoto Protocol are an articulation of how states balance their sovereign right to follow their own development agenda with their overall responsibilities under international law, including those measures aimed at avoiding harm to areas beyond the limits of national jurisdiction. This means that the global nature of climate change demands that states scale back some of their sovereignty by engaging in international cooperation and negotiation in the interest of the "common concern of humankind". ${ }^{08}$ Efforts to curb climate change have given rise - sometimes in conjunction with developments in other environmental regimes - to the evolution of new principles and concepts of international law, including the principle of common but differentiated responsibilities, the notion of common concern of humankind, protection of vulnerable countries and others. ${ }^{109}$ With regard to the application of the responsibility to protect doctrine to climate change it is argued here that existing relevant international obligations such as the responsibility to avoid trans-boundary harm must be seen in a broader context in order to widen the international responsibility to protect people and ecosystems at the same time.

\subsection{CLIMATE CHANGE AND INTERNATIONAL HUMAN RIGHTS LAW}

A s early as 1984, Karel Vasak in his inaugural lecture lat the International Human Rights Institute in Strasbourg proposed the concept of solidarity or third generation rights, including the right to development, the right to peace and the right to a healthy environment. ${ }^{10}$ Such rights

are new in that they may both be invoked against the State and demanded of it; but above all (and herein lies their essential characteristic) they can be realized only through the concerted efforts of all the actors on the social scene: the individual, the State, public and private bodies and the international community. ${ }^{\text {II }}$

The efforts that have been made so far to place rights at the centre of any future climate change dispensation have only recently started to become more human rights focused. One reason for the past silence of human rights regarding climate change is the fact that most international human rights instruments were drafted before the emergence of climate change as a common concern. However, silence is increasingly turning into salience. When looking at the most severe impacts of climate change such as drought, floods, migration and famines it becomes very clear that climate change and its effects affect large numbers of people and have an impact on a broad range of human rights; the right to life in the first place, but also the rights to health, adequate food and water, property and adequate housing, self-determination, to name only the most common and pressing ones.

When it comes to the question of the state of fulfilment of human rights in the world, statistics are frequently consulted. Only some of the respective figures will be given as examples. This seems appropriate because the negative effects of climate change will most affect those people who already appear in one or more of the following figures. In developing regions, 24 per cent of people live on less than US\$1.25 a day. ${ }^{12}$ Globally almost 870 million people (or one in eight) are chronically undernourished, of which 852 million live in developing countries. ${ }^{\prime \prime 3}$ The global under- 
five mortality rate is 45,2 per 1000 live births, ${ }^{1 / 4} 63$ in developing regions. ${ }^{115}$ One in nine people, or 780 million, lack access to an improved water source, 2.5 billion lack improved sanitation, and 3.4 million people die each year from a water related disease. ${ }^{116}$ Over a billion people lack adequate housing 117 and about 1.5 billion have no access to electricity. ${ }^{18}$ Approximately 775 million adults are illiterate ${ }^{119}$ and around 215 million children are child labourers. ${ }^{120}$

There are various reasons why a human rights based approach to climate change is gaining momentum with a high relevance for the future climate change debate. The most important one is probably the cross-fertilisation of human rights and climate change effects and the related mitigation and adaptation measures. With the threats climate change poses to human and environmental security, existing legal structures are likely to come under pressure. ${ }^{121}$ "[H] uman rights obligations may provide a legal baseline for how climate change is tackled and what must be protected from its impacts." 122 Human rights may serve as powerful tools for ensuring greater capacity to adapt to climate change. ${ }^{123}$ In order to design and implement a legal climate change regime that includes the policy value and the legal force of human rights it is required to introduce likely human rights impacts and outcomes of climate change. The experiences gained in the field of human rights law may furthermore be useful sources of information in the processes of climate change related policy and legal drafting. Perhaps jurisprudence particularly related to the effects of climate change has not yet been established by international human rights tribunals. Jurisprudence by international human rights tribunals to address the impact of environmental harm ${ }^{124}$ on human rights, however, may well be extended to also apply to the negative effects of climate change as global environmental harm. Furthermore, climate change impacts on human rights should be considered when adaptation and mitigation measures are being developed and implemented. Tackling the negative effects of climate change may have a positive influence on the fulfilment of human rights. The less the negative effects of climate change, the better the chances to fully enjoy all human rights and fundamental freedoms. Moreover, international human rights law places certain duties on states (in very general terms, the duty to refrain from violating human rights itself, but also to protect its citizens from human rights violations) to address the effects of climate change on human rights, irrespective of their relative contributions of greenhouse gas emissions to global warming.

In the context of climate change, three basic obligations of states can be identified, namely addressing the causes of climate change, i.e. mitigating climate change; addressing the effects of climate change, i.e. adapting to the effects of climate change by reducing risks created by climate change and vulnerabilities caused by it; and addressing the consequences of climate change, for example by protecting individuals displaced by the effects of climate change. ${ }^{125}$

The duty to cooperate ${ }^{126}$ in the international protection of human rights by means of diplomacy, by institutional cooperation on the UN or regional level, or by imposing unilateral or multilateral sanctions to induce a state to comply with human rights obligations is a state obligation that could also apply to climate change related matters. To this end, the United Nations Human Rights Council adopted Resolution 19/33 in 2012, which

[u]rges States to take necessary measures to enhance bilateral, regional and international cooperation aimed at addressing the adverse impact of consecutive and compounded global crises, such as financial and economic crises, food crises, climate change and natural disasters, on the full enjoyment of human rights. ${ }^{127}$

Both the International Covenant on Civil and Political Rights (ICCPR) and the International Covenant on Economic, Social and Cultural Rights (ICESCR), which together with the Universal Declaration of Human Rights (UDHR) form part of the International Bill of Rights, call on state parties to take steps (legislative or other measures) to give effect to the rights contained therein. Both Covenants recognise the right of peoples to self-determination; both have provisions which prohibit all forms of discrimination in the exercise of human rights; and both have the force of law in the countries which have ratified them. Most of the rights and freedoms recognised in the ICCPR are also entrenched in national constitutions' Bill of Rights. This may include, among others, the right to dignity, the right to life, the right to health, the right to water, the right to legal representation, the guarantee against torture and other cruel or inhumane treatment or punishment, and the right to protection against discrimination on any grounds. States have obligations under international human rights law to address disadvantage and threats to human rights and to ensure that policies aimed at limiting the effects of climate change are implemented effectively and in ways that do not overburden or discriminate against specific vulnerable groups, e.g. women, children and indigenous people. ${ }^{128}$ In 2008, the UN General Assembly adopted, by consensus, the Optional Protocol to the ICESCR, which will come into force on 5 May $2013^{129}$ and which provides a mechanism through which persons can petition the UN Committee on Economic, Social and Cultural Rights about violations of their rights.

One starting signal for addressing the linkages between climate change and human rights on the international level has been the United Nations Human Rights Council's first 
resolution on human rights and climate change in 2008. ${ }^{130}$ In 2009, a number of countries called on the Office of the United Nations High Commissioner for Human Rights $(\mathrm{OHCHR})$ to conduct a detailed analytical study of the human rights dimension of climate change, taking into account the views of states and other stakeholders. This study ${ }^{|3|}$ was submitted to the tenth session of the Council held in 2009. In the same year, the Council adopted resolution 10/4 on human rights and climate change, which noted the effects of climate change on the enjoyment of human rights, and reaffirmed the potential of human rights obligations and commitments to inform and strengthen international and national policy making. The Council stated that climate change and human rights are governed by international regimes that have evolved separately, with different premises underlying the legal frameworks of multilateral environmental agreements (like the UNFCCC) and human rights treaties. In 20I2, the Human Rights Council created a new mandate of an independent expert on the issue of human rights obligations relating to the enjoyment of a safe, clean, healthy and sustainable environment. ${ }^{132}$ The new independent expert will among other things serve to identify human rights challenges related to climate change.

It is not only within international human rights law that climate change related issues are moving into the centre of the debate. Also within the international climate change negotiations human rights impacts have gradually become a more relevant aspect. ${ }^{133}$

In fact,

\begin{abstract}
"climate change prompts significant questions about justice and distribution. There is an acute need for intelligent collective action focusing on the human suffering that climate change will cause in future. On the one hand, as a matter of law, the human rights of individuals need to be viewed in terms of state obligations: it is principally the state that is responsible for human rights fulfilment. On the other hand the assignation of such responsibility to only the state seems inadequate, especially in the context of climate change and human security."|34
\end{abstract}

This is also reflected by more recent outcomes of COP to the UNFCCC. One remarkable statement in this regard is the emphasis made by Cancun Decision I/CP.I $6^{135}$ on a human rights oriented approach to deal with all issues relating to climate change, by:

[r]ecognising that climate change represents an urgent and potentially irreversible threat to human societies and the planet, and thus requires to be urgently addressed by all Parties $[\ldots]$

and:

[n]oting resolution 10/4 of the United Nations Human Rights
Council on human rights and climate change, which recognizes that the adverse effects of climate change have a range of direct and indirect implications for the effective enjoyment of human rights and that the effects of climate change will be felt most acutely by those segments of the population that are already vulnerable owing to geography, gender, age, indigenous or minority status, or disability $[\ldots]$

Moreover, the Conference of the Parties:

[e]mphasises that Parties should, in all climate change related actions, fully respect human rights.

The inclusions of human rights wording and concepts in the Cancun Agreements represents a unprecedented recognition of the fundamental link between human rights and climate change, and the first tangible results of years of patient analysis, advocacy and alliance building by communities vulnerable to climate change. Rights have become a relevant part of this discourse. ${ }^{136}$

With all due respect for the importance of human rights law for the climate change related problems with which mankind is confronted, one should, however, not turn a blind eye to some of the challenges of international human rights law that might contribute to the disadvantage of those living in the regions most vulnerable to climate change, and particularly those segments of the population who are most vulnerable to the negative effects of climate change, namely women, children and indigenous people. Such challenges include insufficient enforcement mechanisms, the difficulty to establish extraterritorial responsibility and local accountability, the possibility of derogation from many human rights in times of emergency that may be declared in case of catastrophic events such as floods and droughts, or conflicting human rights, e.g. the human right to property or peaceful enjoyment of possessions to prevent or reduce action on climate change. ${ }^{137}$

Several international human rights mechanisms are being used to drive action on climate change. ${ }^{138}$ Besides the Human Rights Council's Special Rapporteurs and Special Representatives of the Secretary-General, who conduct country missions, comment on country situations and receive human rights complaints, among other things, the Universal Periodic Review operating since 2008 under the umbrella of the Human Rights Council has become a useful mechanism for states particularly vulnerable to climate change to highlight the threats of global warming to people's rights. Within the process of this peer review, the degree to which a $U N$ member state is complying with international human rights law and domestic laws and commitments is being reviewed every four-and-a-half years by other UN member states. In the period from 2008 to 20 I I, 3 I states have raised climate change related concerns in the national reports and thereby at least 
placed some moral pressure on high-emitting developed states. ${ }^{139}$ Reports by human rights treaty bodies will have "persuasive force insofar as the organs retain their independence, deliver reasoned and consistent opinions using accepted methods of treaty interpretation, and establish a pattten of compliance by State Parties"|40

\subsection{CLIMATE REFUGEE LAW?}

In terms of international legal instruments, it must be stated that the issue of climate induced migration is only fragmentarily regulated. There is no single international agreement applicable and neither existing climate change law nor refugee law adequately provides for a consolidated legal framework. Voices asking for a standalone international legal regime addressing climate change induced migration are becoming louder. ${ }^{141}$ The following two legal regimes and their scope of application show the difficulties for the international and African context.

The movement of persons across international borders due to climate change related events prompts several questions and challenges to international law. The Geneva Refugee Convention of I95 I defines a refugee as a person with a

well-founded fear of being prosecuted for reasons of race, religion, nationality, membership of a particular social group or political opinion, is outside the country of his/her nationality and is unable or, owing to such fear, is unwilling to avail himself/herself of the protection of that country; or who, not having a nationality and being outside the country of his/her former habitual residence as a result of such events, is unable or, owing to such fear, unwilling to return to it. ${ }^{142}$

Unfortunately this definition provides numerous complications in attempting to classify climate refugees as refugees under international refugee law. The scope of application of the Geneva Refugee Convention for climate refugees is questionable per se; in any case, it would only be applicable to those migrants who have crossed borders, as it does not provide for internal displacement.

The legal distinction between those moving voluntarily (rather referred to as migrants) and those being forcibly displaced across borders (rather referred to as displaced persons) with the respective legal consequences does not adequately capture the reality of migration as an adaptation strategy, which cannot clearly be allocated under one of the two categories. ${ }^{143}$ Once a person has migrated across an international border because of climate change related events and does not qualify as refugee, the only set of legal norms that applies is international human rights law. A right to stay on foreign territory can only be "derived from the human rights prohibition of inhuman treatment - of forcible return of people to a country where they would be exposed to serious risks to life and health",'44 and international law is lacking a set of status rights, particularly for those migrating as a measure of adaptation to climate change.

New strategies and legal frameworks will have to be developed and negotiated to adequately address climate change related cross-border movement of persons. These should particularly encompass the following aspects: 145

I. Preventing displacement through disaster risk and vulnerability reduction and other adaptation measures;

2. Managing migration as adaptation measures;

3. Providing temporary protection status for persons displaced to other countries and permanent admission in cases where return turns out to be impermissible, impossible or cannot be reasonably be expected over time; and

4. Organizing resettlement/relocation for populations of lowlying small island states and other states losing substantial amounts of their territory.

The issue of internal displacement has been taken up by the African Union by adopting the African Union Convention for the Protection and Assistance of Internally Displaced Persons in Africa in Kampala in 2009. As of 17 January 20 I3, the Kampala Convention had 36 signatories, 16 countries $^{146}$ had ratified it and it has entered into force on 6 December 2012. It is the first regional legal instrument in the world containing legal obligations for states with regard to the protection and assistance of Internally Displaced Persons (IDPs). The Kampala Convention defines IDPs as:

persons or groups of persons who have been forced or obliged to flee or to leave their homes or places of habitual residence, in particular as a result of or in order to avoid the effects of armed conflict, situations of generalized violence, violations of human rights or natural or human-made disasters, and who have not crossed an internationally recognized State border. ${ }^{147}$

The Convention explicitly recognises its relevance for climate change induced displacement, as it is states in Article 5 that "States Parties shall take measures to protect and assist persons who have been internally displaced due to natural or human made disasters, including climate change." However, the Kampala Convention applies to all situations of internal displacement regardless of its causes (Article 15).

\subsection{CLIMATE CHANGE,THE OCEANS AND THE LAW OF THE SEA}


T he intersection of climate change with the law of the sea cannot be denied. Where the impacts of climate change manifest themselves within the oceans arena sovereignty questions arise and have the potential to manifest themselves in areas beyond national jurisdiction. The oceans cover more than 70 per cent of the earth's surface and play a pivotal role in the climate change debate. On the one hand, the oceans must be seen as victims of climate change. Changes in ocean temperature and heat content, changes in ocean salinity, changes in sea level and biogeochemical changes (ocean acidification in particular) all have severe consequences, not only for marine ecosystems. ${ }^{148}$ The last Assessment Report of the IPCC (AR4) projected sea level rise to range from 0.18 to $0.59 \mathrm{~m}$ (depending on the scenario) at the end of the 2 I st century (2090-2099). ${ }^{149}$ Primary contributors to global average sea level change are the expansion or contraction of the ocean due to changes in temperature and the transfer of water, particularly from glaciers and ice sheets.

On the other hand, the oceans are also a part of the solution, playing a significant role in effectuating climate change impacts. The oceans are the largest sinks of $\mathrm{CO} 2$ as well as the largest heat sinks. The oceans, by interacting with the atmosphere, create heat circulation and wind and weather patterns, which determine the impacts of climate change on all terrestrial life. ${ }^{150}$ The oceans absorb one quarter of human emissions of carbon dioxide annually, ${ }^{151}$ acting to slow the rate of climate change. ${ }^{152}$

The law of the sea is faced with considerable challenges regarding the impacts of climate change on the oceans. ${ }^{153}$ Fields of international law that come to mind with regard to the effects of climate change on the oceans are international fisheries law and the broader field of marine environmental law. Furthermore, sea level rise and the opening of previously ice-covered ocean areas present navigational rules, the law pertaining to the protection of sensitive polar marine environments, but in particular international law relating to entitlement to maritime zones with a number of challenges.

Besides a large set of international treaties governing various aspects of marine pollution ${ }^{154}$ and biodiversity protection, $^{155}$ the 1982 United Nations Convention on the Law of the Sea (UNCLOS III) is the main international legal instrument in terms of marine governance. ${ }^{156}$ With I 65 parties, ${ }^{157}$ the Convention is a broadly applicable set of rules defining the rights and responsibilities of nations in their use of the world's oceans and establishing guidelines for the environment and management of marine natural resources. However, it seems that UNCLOS does not provide sufficient rules to resolve the problems related to the effects that climate change has on the oceans.

UNCLOS III provides that states are entitled to four types of maritime zones: the territorial sea (which may not exceed 12 miles in breadth and over which the coastal state is sovereign); the contiguous zone (up to 24 miles in breadth, in which the state may exercise jurisdiction over customs, immigration and pollution); the exclusive economic zone (up to 200 miles, in which the state has exclusive rights to explore and exploit natural resources, establish artificial structures, conduct scientific research, and protect the marine environment); and the continental shelf (not exceeding 350 miles, in which the state possesses sovereign rights for the purpose of exploring and exploiting the natural resources). Besides processes such as explosions or eruptions, climate change related changes of the oceans with sea level rise leading the way are further causes for shifts in coastal geography, which in turn directly impact maritime entitlements. It is presumably attributable to the lack of sufficient knowledge of climate change at the time when UNCLOS was concluded in 1982, that the convention remains silent on whether baselines for maritime zones are ambulatory (i.e. whether maritime zones shift with the coastline) or fixed. ${ }^{158}$

The threats of climate change and sea level rise present international law with massive legal challenges. Sea level rise rendering small islands uninhabitable is an extreme scenario, which is certainly not applicable to all small island nations. It, however, puts to the fore the effects of climate change on socio-economic conditions and bio-physical resources and many of the challenges with which the law of the sea (and many other fields including refugee law, human rights law, etc.) ${ }^{159}$ is confronted in the era of climate change. The options for small island states, which potentially lose statehood and maritime claims due to sea level rise, are increasingly being explored, on paper and in practice. One option to maintaining maritime zones and statehood, which has been suggested, realised and controversially discussed, not only from a legal point of view, is the construction of artificial islands. ${ }^{160}$ However, a solution to the legal problems of the consequences of climate change induced sea level rise at international level is not yet in sight.

Lastly, new technology permits companies to exploit oil and gas reserves in the newly accessible continental shelf. Improvements in deep seabed mining technology make it feasible to extract rare earth and other minerals from the ocean floor outside of any nation's jurisdiction. Newly available oil and gas exploration, shipping, tourism and fishing in the Arctic as a result of global warming has a variety of security implications in newly accessible Arctic sea routes as well as in other potentially contested sea lanes, i.e. in the South China Sea and in the Antarctic.

The high seas, one of the four global commons, ${ }^{161}$ have to be protected from environmental threats caused by deep-sea mining, overfishing, ocean warming, acidification and pollution. The protection of the high seas in terms 
of security threats, however, also plays an important role in the international trade arena. The United Nations International Maritime Organization estimates that over 90 per cent of world trade are carried by sea. The global network of merchant ships thus provides one of the most important modes of transportation. ${ }^{163}$

Piracy may have serious implications for the continued economic development of many regions and is becoming a major challenge for international law. International law addresses the issue of piracy particularly in Articles 100107 and IIO of the UNCLOS. Article 10I, UNCLOS provides that:

\section{piracy consists of any of the following acts:}

(a) any illegal acts of violence or detention, or any act of depredation, committed for private ends by the crew or the passengers of a private ship or a private aircraft, and directed:

(i) on the high seas, against another ship or aircraft, or against persons or property on board such ship or aircraft;

(ii) against a ship, aircraft, persons or property in a place outside the jurisdiction of any State;

(b) any act of voluntary participation in the operation of a ship or of an aircraft with knowledge of facts making it a pirate ship or aircraft;

(c) any act of inciting or of intentionally facilitating an act described in subparagraph (a) or (b).

The welfare of seafarers and the security of navigation and commerce are at risk due to acts of piracy, which may result in the loss of life, physical harm or hostagetaking of seafarers, significant disruptions to commerce and navigation, financial losses to ship-owners, increased insurance premiums and security costs, increased costs to consumers and producers, and damage to the marine environment. The Division for Ocean Affairs and the Law of the Sea has reported as follows:

In the first six months of 2012, 206 attacks were reported worldwide, compared with 316 attacks during the same period in 201 I. The total number of acts or attempted acts of piracy and armed robbery at sea worldwide, as reported to IMO in 20I I, was 544, compared with 489 in 2010.

At the regional level, in 201 I IMO received 223 incident reports for East Africa; 63 for the Indian Ocean; 28 for the Arabian Sea; I 13 for the South China Sea; 22 for the Straits of Malacca and Singapore; 29 for South America and the Caribbean; and 61 for West Africa. ${ }^{164}$

Especially developing countries are increasingly building up their marine military forces to address current threats such as depletion of natural resources and hazards of maritime transport routes by piracy. ${ }^{165}$ As continuous economic growth can only be achieved if a safe passage of goods, raw materials and energy is warranted, defence budgets are being increased.

China, for example, who transports 95 per cent of its imports and exports via the oceans, has increased its budget for armament by 216 per cent from 2000 to 2009 , with upgrading the submarine fleet as a focus area. India, in its 2007 Maritime Military Strategy, recognises a direct link between national economic development and open sea routes. ${ }^{166}$ Brazil's National Strategy of Defence ${ }^{167}$ provides that:

"Sea denial", "sea control" and "power projection" should focus, without defining any hierarchy for the objectives, and according to the circumstances, on the following:

a) Proactive defence of the oil platforms;

b) Proactive defence of naval and port facilities, archipelagos and oceanic islands located within the Brazilian jurisdictional waters;

c) Promptness to respond to any threat against sea-lanes of trade, by States, or by non-conventional or criminal forces;

d) Capacity to join international peacekeeping operations outside of the territory and the Brazilian jurisdictional waters, under the aegis of the United Nations or other multilateral organizations in the region.

South Africa, as one example of a developing nation on the African continent, and considered to be the most powerful nation on the continent in military terms, ${ }^{168}$ also considers its navy to be an important tool to secure free and safe passage for trade vessels and thereby to contribute towards regional stability. Approximately 98 per cent of South Africa's international trade moves by sea and the prosperity of the region is highly dependent on the stability and unhindered flow of trade into and out of the region. ${ }^{169}$

In this context is noteworthy that Africa is now taking legal action "to liberate African coastal waters from ageold foreign dominance, and take a significant step towards a more unified continent"170 and thus taking another significant step away from the remains of colonialism. The African Union has come up with an African Maritime Transport Charter (which still has to come into force) ${ }^{171}$ and is about to conclude plans to establish an African Cabotage Regime, which will only allow African vessels to move cargo along the coast of the continent and prevent non-African mother vessels in African waters from using smaller vessels to move products back and forth in African waters. The aim is to support the African shipping industry by only allowing African owned vessels to trade along Africa's coast. 


\subsection{CLIMATE CHANGE AND WORLD TRADE LAW}

Tientente he international trade regime under the World Trade Organisation (WTO) is also strongly related to the international climate change regime. In fact, both regimes recognise that climate change may provide opportunities as well as challenges for international development. The WTO is a remarkable example of institutional evolution and its dispute settlement system is as effective as it is impartial. However, similar to the international climate change negotiations, the socalled Doha Development Round of multilateral trade negotiations have been complex and without success so far. Both negotiation processes seem to be lacking the necessary consensus of the parties involved. The only difference between the two negotiation processes lies in the fact that "the climate doesn't have time for a Dohalike approach". 172 Unfortunately, after more than 10 years of repeated negotiation failures, the Doha Development Round is unlikely to be concluded in the near future. Some even contend that the "WTO risks its future by keeping Doha alive". ${ }^{173}$

With regard to the persistence of global poverty and socio-economic inequalities, international trade rules often allow affluent countries to continue to protect their markets - with tariffs, quotas, anti-dumping duties, export credits and huge subsidies to domestic producers - at the expense of potential agricultural and textile exports from developing countries, for example,.. ${ }^{174}$ International trade should therefore be considered as a means to an end, but not as the end in itself. An effective international trade regime must first and foremost be friendly to the environment, poverty reduction and sustainable development. ${ }^{175}$ The increasing awareness about the negative effects of climate change and the continuing communication among international institutions as well as the public dialogue necessarily lead to the rethinking and eventually to the adjustment of traditional frameworks. These also lead to fruitful discussions, for example, on new trade and climate change related measures, such as carbon labelling or similar standards or regulations on the imposition of border carbon adjustments, which impose border taxes on the embodied carbon of imported goods, set at the level of equivalent domestic taxes. ${ }^{176}$

In the light of the fact that the global village, with international trade as a foundation, has become a reality, it is commendable that the 'trade versus environment' debate has shifted towards the concept of mutual supportiveness between trade and environment or trade and climate change respectively, even though it might - at first glance - appear to be a forced marriage. ${ }^{177}$

Again, world trade law "can both constrain and enable climate action". ${ }^{178}$ World trade law has the potential to promote community goals, namely the enhancement of economic development. ${ }^{179}$ A closer look at world trade law, however,

sadly shows that accordingly solidarity is poorly implemented. The flaw is not in WTO law itself: WTO law allows developed countries to act in favour of developing countries. But developed countries can choose not to implement relevant exceptions and too often implement them poorly. ${ }^{180}$

Moreover, both the policy-making and academic communities have been focusing on the role of the WTO. ${ }^{181}$ There has been much discussion about the ways in which the WTO exerts a negative influence on climate law and policy. This includes its potential 'chilling' effect on the climate treaties, referring to the fact that parties to the climate regime have refrained from adopting multilateral trade measures - for instance, against non-compliers or non-parties. ${ }^{182}$ While WTO law may thus seem to constrain climate ambitions, attention has increasingly shifted to ways that the organisation might contribute to climate change mitigation. One of these options is pursuing the reduction of fossil fuel subsidies, ${ }^{183}$ as called for by the G20 in 2010.184

With the aim to achieve a global agreement to tackle aviation emissions, the European Union (EU) has since the beginning of 2012 included emissions from international aviation into the EU Emission Trading System (EU ETS), which applies to EU and non-EU airlines alike.185 The recent independent action by the EU on international aviation emissions ${ }^{186}$ has given rise to a boiling international dispute whereby the EU has been accused of using unilateral trade measures and exercising extraterritorial jurisdiction in violation of international law, ${ }^{187}$ and failing to adequately reflect the principle of 'common but differentiated responsibilities and respective capabilities' (CBDRRC) in the design of its aviation scheme. ${ }^{188}$

Similar opposition is to be expected if the EU applies measures to emissions from international shipping. These are estimated to be responsible for 2.7 per cent of the global CO2 emissions in 2007. 189 Since the International Maritime Organisation (IMO) is struggling to agree upon global action on measures such as a levy on $\mathrm{CO} 2$ emissions or a cap-and-trade scheme for curbing emissions from shipping, the European Commission is considering to including maritime transport emissions in the EU's greenhouse gas reduction commitment. ${ }^{190}$ It becomes clear that powerful states can turn to unilateralism when they decide that they may achieve their foreign policy goals by unilateral action rather than by cooperation. ${ }^{191}$ This in turn reflects that the international system is still 
characterised "by gross inequalities in power". ${ }^{192}$

While the question of response measures remains sensitive in UNFCCC negotiations, the forum could provide for a multilateral dialogue to examine the implications of unilateral climate action designed to promote the ultimate objective of the UNFCCC. In some cases, the WTO dispute settlement mechanism could also enter the scene if the measure in question falls under WTO Agreements.

In all cases, however, the focus should shift from the relatively simplistic choice between multilateral action, unilateral action or no action ${ }^{193}$ towards exploring ways in which interaction between a plural mix of legal regimes and jurisdictions in a global context can best serve the ultimate objective of the UNFCCC to avoid dangerous anthropogenic climate change. ${ }^{194}$

Thus, more international cooperation in economic areas is necessary in order to ensure more coherence and global welfare. ${ }^{195}$

It is not surprising that given the broad scope of subjects covered by international economic law in general and the law of the WTO in particular - cooperation in these fields show the variety of modes and mechanisms to implement obligations to cooperate. ${ }^{196}$

After all, while world trade has - no doubt - contributed significantly to greenhouse gas emissions, it also offers a variety of options in terms of new technologies and services, which will be crucial in mitigating further climate change.

Lastly, climate induced migration on the scale that is expected is not unlikely to have serious repercussions socially, economically and politically. In this sense, it is worth examining the implications such displacement may have for international trade. ${ }^{197}$ Some authors have started to approach international trade from an anti-capitalist perspective, linking trade to migration by arguing that the multilateral economic system is a capitalist one, whereby strong capitalist interests are protected by regulatory regimes such as the World Trade Organisation (WTO) to continue exploiting the ecosystem in an unsustainable way in pursuit of profit. The environmental damage, in turn, leads to the displacement of people who are forced to migrate by the lack of resources and the basics for survival. ${ }^{198}$

\section{THE FUTURE WE WANT?}

Erom the aforementioned it becomes clear that the - existing regimes and intersections of law may not yet suffice to assure the best possible outcomes for future generations. This, among other things, was addressed at the 2012 Rio+20 Conference on Sustainable Development, which was the biggest UN conference ever. The conference should have been a major step forward in achieving a sustainable future - the future we want. This, however, did not happen due to a number of reasons, so that "the future we want" still needs further political attention and action.

The 2012 Club of Rome Report entitled "2052 - A Global Forecast for the Next Forty Years", 199 addresses several global goals as essential for the transition towards a sustainable, equitable and 'happier' world. Some of these global goals are also most relevant to the challenges of the Anthropocene: The report argues that societal values are essential for a sustainable and equitable society and that they must be fully reflected in all economic decisions. It further contends that a more equitable distribution of income both within and between countries is required. Moreover it holds that the ecology must be seen as a binding constraint for all forms of human activity and should therefore be managed in a manner which reflects its biophysical and economic value. Never should the world be in overshoot. Appropriate governance systems at a local, national and global level must be established to manage the transition into an equitable and sustainable global world. 200

In the light of the aforementioned the following sections will reflect in more detail on the way forward and make some recommendations for the future we (may or may not) want.

\section{I ECONOMIC DEVELOPMENT, REGIONAL INTEGRATION AND THE REDUCTION OF POVERTY}

he furtherance of economic development, regional
integration, and the reduction of poverty go hand in hand. ${ }^{201}$ This interrelationship has become closer over the past few years due to increasing discussions in the world community on the issue, especially in the context of climate change. Yet, many regional integration processes around the world still face obstacles and challenges. ${ }^{202}$ The fear of losing state autonomy, the fear of losing national identity, socio-economic disparity among members, historical disagreement, lack of vision, and unwillingness to share resources are some of the obstacles that present themselves with regard to regional integration. ${ }^{203}$ Regional 
integration provides an

opportunity to enhance political stability by establishing regional organisations, which play an increasing role (not only in the facilitation of trade but also) in defusing conflicts within and between countries and in promoting human rights. In terms of climate change related matters, such organisations are of the utmost relevance, especially when it comes to climate change related disaster management and environmentally induced migration. In this context, regional integration may serve as a tool to maintain political stability by building trust, enhancing understanding between groups and deepening interdependence. $^{204}$

The triumph of market mechanisms has accelerated the process of globalisation. After the collapse of the competition between market-driven and statecommanded economies, developing countries seem to have only one option to follow for modernisation and development. Liberal democracy does not seem to have any serious competitors. Given this monolithic economic and political framework, it is not an easy task to determine where sustainable economic development actually fits in. ${ }^{205}$ The same applies to the question regarding the relation between market, development and wellbeing, and the influence economic development can play on the alleviation of poverty in view of the fact that economic development is not always concomitant with greater welfare of the average individual, as the growth of the gross national product (GNP) is not a sufficient indicator with which to measure the level of security and the quality of life of people.

After all, it is a sad reality that about half of all human beings still live in severe poverty ${ }^{206}$ and about a quarter live in extreme or life-threatening poverty. One major reason why poverty is still so prominent today is that "affluent societies are not merely helping too little, but also harming too much."207 The principle of common but differentiated responsibilities (CBDR), one of the cornerstones of the international climate change regime, explicitly referred to in the UNFCCC and the Kyoto Protocol, is meant to address this disparity. The trans-boundary nature of climate change action and impacts have environmental and developmental repercussions for all countries. The differentiation of responsibilities, however, should support even greater efforts in future, ${ }^{208}$ especially in view of the on-going "disparity between the human and the economic magnitude of world poverty" and "the enormous extent of economic inequality in the world today". ${ }^{209}$ About 60 per cent of the world's population holds less than 2 per cent of global wealth, in contrast to the top I per cent of the world's population, who hold 40 per cent of global wealth. ${ }^{210}$ "Because of these enormous inequalities, we are now at the point where the world is easily rich enough in aggregate to abolish all poverty. We are simply choosing to prioritize other ends instead."2II Sustainable economic development therefore depends on equity:

In the analysis of the causes of and solutions to climate change, the quality of the equity commons and the governance rules that protect and enhance it are key elements in crafting a viable international agreement on future emissions allocation and burden-sharing of emissions mitigation and climate adaptation costs. More broadly, equity - together with so many of the public goods that provide the foundation for $[. .$.$] sustainable development$ - is vulnerable. Deliberate policies in favour of increasing equity over time not only improve social welfare, but also act to shore up the foundations for the equity commons of the future, by establishing and strengthening rules for its governance. ${ }^{212}$

\subsection{COOPERATIVE GLOBAL CLIMATE GOVERNANCE}

Ithough the problem of climate change is rather clear, political solutions are often far and unfair. The international community seems unable to come up with agreements that both remedy the substantive causes of climate change and the damage caused by it. An agreement that is optimal for the world and its future generations may not be optimal for some national economies, which would probably have to bear a large burden for significant domestic emissions reductions and which are not among the nation's most gravely affected and threatened by climate change. The key remaining question is how responsibility for global climate protection can be shared more equitably in future. In order for that to happen more effective and equitable legal and policy responses need to be implemented.

We live in an increasingly interconnected and interdependent world. It is a world bound together, not just by state interests, but also - and especially in the context of climate change - by an interest in more global cooperation. ${ }^{213}$ It should thus be "in the interests of all States [...] to uphold the rule of law in the world." 214

Yet, it would be irrational to accept more powerful organs of world government, without a certain decrease of national government's power. ${ }^{215}$ According to a minimal definition of cooperation the term could mean that states are to enter into contact with each other. ${ }^{216}$ It could further be argued that under general international law states are under an obligation to cooperate, 217 an effort for instance "to accomplish an object by joint action, where the activity of a single state cannot achieve the same result". ${ }^{218}$ Areas where international cooperation is essential include the international protection of human rights, the duty to cooperate in international economic 
law and related areas, and the duty to cooperate in international dispute settlement. ${ }^{219}$

On the one hand international duties to cooperate are based on treaties made by the sovereign states, which leaves it in their discretion whether they adhere to that treaty or not.220 On the other hand one can also argue that cooperation by states actually is "the most important manifestation of sovereignty",221 rather than - "as was assumed in earlier times - an obstacle to international cooperation". 222 However, it must "be admitted that the hard law obligations to cooperate share the fate of other binding rules of international law, i.e. that some States still prefer not to comply" with them. ${ }^{223}$

In the analysis of the causes of and solutions to climate change more "[d]eliberate policies in favour of increasing equity over time [would] not only improve social welfare, but would also act to shore up the foundations for the equity commons of the future, by establishing and strengthening rules for its governance". 224 Yet, in the development of international law it is so far "precipitate to consider solidarity as a legally binding principle for all in international law. All too often its content is too uncertain for it to work as an applicable legal norm."225

According to the UN General Assembly's definition of solidarity in the UN Millennium Declaration "[g]lobal challenges must be managed in a way that distributes the costs and burdens fairly in accordance with basic principles of equity and social justice. Those who suffer or who benefit least deserve help from those who benefit most."226 Common but differentiated responsibilities as stipulated in Principle 7 of the Rio Declaration states: "States shall cooperate in a spirit of global partnership to conserve, protect and restore the health and integrity of the earth's ecosystem. In view of the different contributions to global environmental degradation, States have common but differentiated responsibilities."227

International law as a value-based order should go beyond mere coexistence and involving the commonly shared interests of the international community. 228 Solidarity has long been invoked as a strong moral claim but it is more and more considered to be a "value reflected in international law". 229 Solidarity involves three different, not necessarily cumulative aspects:.230 "The achievement of common objectives through common action of States, the achievement of common objectives through differentiated obligations of States and actions to benefit particular States". ${ }^{231}$

Yet, from the above it becomes clear that several independent international legal regimes exist, which are relevant in one way or another in the context of climate change. There are intersections between these regimes although they are fragmented. On the one hand such fragmentation and regulatory diversity may well be beneficial if the intersections of law are orchestrated in an innovative manner. On the other hand it is argued here that the law (at least as it exists today) is not enough to effectively address the challenges that accompany climate change. While there are some regimes dedicated exclusively to climate change (such as the UNFCCC), others impact deeply on climate change, yet have a primary focus dealing with quite different subjects (human rights, world trade, the oceans framework etc.). Dealing with climate change involves creating a coherent and orchestrated international regime, a set of arrangements among states and other stakeholders designed to solve a global problem that cannot be solved by individual nation-states. While the existing international regimes rest largely on intergovernmental agreement, one dealing with climate change will have to go far beyond the capacity of governments and will need support from non-state actors as well, creating a multi-stakeholder regime. ${ }^{232}$ For local and national action to be effective, such a global regime should aim at cooperation and solidarity, and be supportive and well designed.

Human activities seem to be moving several of the Earth's sub-systems outside the range of natural variability typical for the previous 500000 years. ${ }^{233}$ Human societies therefore must now change course and steer away from critical tipping points in the Earth system that might lead to rapid and irreversible change. ${ }^{234}$

\begin{abstract}
This requires fundamental reorientation and restructuring of national and international institutions toward more effective Earth system governance and planetary stewardship [...]. The world saw a major transformative shift in governance after 1945 that led to the establishment of the UN and numerous other international organizations, along with far-reaching new international legal norms on human rights and economic cooperation. We need similar changes today, a 'constitutional moment' in world politics and global governance. ${ }^{235}$
\end{abstract}

At the same time international law and global governance will require more empowerment of international judicial institutions that learn to integrate inter-disciplinary tools to accommodate the inter-linkages between legal and institutional reforms and climate change policy.

\section{CONCLUSION}

To conclude with a statement made by UN Secretary-General Ban Ki-moon in February 2013: "We live in an age of monumental transition - economic, demographic, political. Global interdependence is deepening. Transnational threats are growing. This means we must make better use of the United Nations machinery." So far, however, ${ }^{236}$ 
the climate change regime complex is a loosely coupled system of institutions; it has no clear hierarchy or core, yet many of its elements are linked in complementary ways. It occupies neither extreme. Instead, it is a regime complex whose elements are loosely linked to one another, between the poles of integration and fragmentation. ${ }^{237}$

In the threatening context of climate change this can be interpreted as a failure of the system: More coherent, cooperative, collective action is needed to address climate change. The piecemeal, fragmentary approach to both understanding and addressing the issue of climate change is unsatisfactory. Humanity has the opportunities, tools, science, technology and insight to deal with climate change and to move into a better world. Whether we manage to do so will depend on improved mechanisms of international law and governance. The failure to bring international relations under the rule of law through the absence of more effective central mechanisms of adjudication and/or enforcement explains the pervasive ambiguity of international law..$^{238} \mathrm{In}$ fact, what is missing is more world government, a strengthening of the central organs of the United Nations, for example, that would make it more likely that international law will be applied and enforced.

Legitimate voices ${ }^{240}$ have been aired regarding the need of a specialised international judicial body to hear and determine trans-boundary environmental matters and to provide greater coherence to the fragmented global climate governance regime. Such a judicial body could provide interpretive guidance and judicial support, which in turn would - no doubt - also be of benefit when combating climate change. It could thus contribute to coordination of the intersections of law, to legal harmonisation and to a complementation of existing fragmented climate relevant regimes.

Such a judicial body would also be in line with Article I 4 of the UNFCCC (dispute resolution) and particularly Article 33(I) of the UN Charter:

The parties to any dispute, the continuance of which is likely to endanger the maintenance of international peace and security, shall, first of all, seek a solution by negotiation, enquiry, mediation, conciliation, arbitration, judicial settlement, resort to regional agencies or arrangements, or other peaceful means of their own choice.

It could resolve conflicting international law obligations and overlapping mandates of the global climate governance structures; create a model for compliance and enforcement to encourage national protection standards; and promote greater accountability and access to justice.

Lastly, existing intersections of law and more cooperative global climate governance can "develop an unforeseen dynamism, in particular if [...] endowed with institutions of a norm-setting and also of a judicial character". ${ }^{241}$ However, the law only enfolds "effective force from the underlying political consensus. Without such consensus, legal devices, no matter how scrupulously they have been thought out, may be swept away by the ground forces active in international society". ${ }^{42}$

The threats of the very existence of humanity are obvious: In this respect, in no area of law should the common interests of mankind be clearer than when addressing climate change and the challenges in the Anthropocene. With this in mind one should reasonably think that it is possible to identify and agree upon the necessary reforms in response to the changing climate and for the survival of mankind. 


\section{Endnotes}

' Cf. World Bank "New report examines risks of 4 degree hotter world by end of century" (I8| I-20 I2) http://www.worldbank.org/en/news/20 I2/ | // 8/new-report-examines-risks-ofdegree-hotter-world-by-end-of-century (accessed 13-12-2012).

${ }^{2}$ The Anthropocene: A man-made world - Science is recognising humans as a geological force to be reckoned with The Economist (26-05-20 I I). http://www.economist.com/node/l 874I 749 (accessed 16-02-2013).

${ }^{3}$ The Anthropocene: A man-made world - Science is recognising humans as a geological force to be reckoned with The Economist (26-05-20 I I) http://www.economist.com/node/ I874 I 749 (accessed 16-02-2013).

${ }^{4}$ See http://www.clubofrome.org/?p=703 (accessed I6-02-2013).

${ }^{5}$ See http://www.clubofrome.org/?p=703 (accessed I6-02-2013).

${ }^{6}$ See http://www.clubofrome.org/?p=703 (accessed 16-02-2013).

${ }^{7}$ International Law Commission (ILC) Draft Article 3 on the protection of persons in the event of disasters of the International Law Commission A/CN.4/L.758 (24-07-2009) http://daccessdds-ny.un.org/doc/UNDOC/LTD/G09/626/84/PDF/G0962684.pdf?OpenElement (accessed 1602-20।3).

${ }^{8}$ IPCC Managing the risks of extreme events and disasters to advance climate change adaptation. A special report of Working Groups I and II of the Intergovernmental Panel on Climate Change (20 I2).

9 Cf. World Bank "New report examines risks of 4 degree hotter world by end of century" (I8| | -20 I2) http://www.worldbank.org/en/news/20 I // | / / 8/new-report-examines-risks-ofdegree-hotter-world-by-end-of-century (accessed 13-12-2012).

10 IPCC Managing the risks of extreme events and disasters to advance climate change adaptation. A special report of Working Groups / and II of the Intergovernmental Panel on Climate Change (2012).

"IPCC Managing the risks of extreme events and disasters to advance climate change adaptation. A special report of Working Groups I and II of the Intergovernmental Panel on Climate Change (2012) 9.

${ }^{12} \mathrm{G}$ Evans "Rethinking collective action: The responsibility to protect and a duty to prevent. The policy challenge" (2004) 98 American Society of International Law Proceedings 78-89.

${ }^{13}$ See World Bank World Development Report 2010: Development and climate change (20 I0) 37-38 and SM Gardiner "Ethics and global climate change" (2004) II 4 Ethics 576. ${ }^{14}$ DR Macer, J Moss, M McMann, J Rae, A Zipprich, A Nyambati, D Ngo, MM Cheng, N Manohar \& G Wolbring Energy equity and environmental security, ethics and climate change in Asia and the Pacific (ECCAP) (20I I) I 3.

${ }^{15}$ DR Macer, J Moss, M McMann, J Rae, A Zipprich, A Nyambati, D Ngo, MM Cheng, N Manohar \& G Wolbring Energy equity and environmental security, ethics and climate change in Asia and the Pacific (ECCAP) (20I I).

${ }^{16}$ C McKinnon "Runaway climate change: A justice-based case for precautions" (2009) 40:2 Journal of Social Philosophy 200.

${ }_{17}$ UNDP 1994: Human Development Report (1994).

${ }^{18}$ SA Ahmed, NS Diffenbaugh \& TW Hertel 2009 "Climate volatility deepens poverty vulnerability in developing countries" (2009) 4:3 Environmental Research Letters I-8.

${ }^{19} \mathrm{JH}$ Kotir "Climate change and variability in Sub-Saharan Africa: A review of current and future trends and impacts on agriculture and food security" (2010) 13:3 Environment, Development and Sustainability 587-605.

${ }^{20} \mathrm{~F}$ Lecocq \& Z Shalizi "How might climate change affect economic growth in developing countries? A review of the growth literature with a climate lens." (2007) 4315 The World Bank Development Research Group Sustainable Rural and Urban Development Team Policy, Research Working Paper.

${ }^{21}$ KR Hope Sr "Climate change and poverty in Africa" (2009) I6 International Journal of Sustainable Development \& World Ecology $451-461$. 
${ }^{22}$ A Costello, M Abbas, A Allan, S Ball, S Bell, R Bellamy, S Friel, N Groce, A Johnson, M Kett, M Lee, C Levy, M Maslin, D McCoy, B McGuire, H Montgomery, D Napier, C Pagel, J Patel, J de Oliveira, N Redclift, H Rees, D Rogger, J Scott, J Stephenson, J Twigg, J Wolff \& C Patterson "Managing the health effects of climate change" (2009) 373:9676 Lancet 1693-1733.

${ }^{23}$ GC De Magny, JF Guégan, M Petit \& B Cazelles "Regional-scale climate-variability synchrony of cholera epidemics in West Africa" (2007) 7 BMC Infectious Diseases 20.

${ }^{24}$ CC Jansen \& NW Beebe "The dengue vector Aedes aegypti: What comes next" (2010) 12 Microbes Infect 272-279.

${ }^{25}$ LE Cuevas, I Jeanne, A Molesworth, M Bell, EC Savory, SJ Connor \& MC Thomson "Risk mapping and early warning systems for the control of meningitis in Africa" (2007) 25 Vaccine A|2-A|7.

${ }^{26}$ See for example J Scheffran \& A Battaglini "Climate and conflicts: The security risks of global warming" (20 I I) I | Regional Environmental Change S27-S39; J Barnett \& N Adger "Climate change, human security and violent conflict" (2007) 26 Political Geography 639-655; R Nordås \& NP Gleditsch "Climate change and conflict" (2007) 26:6 Political Geography 627-638; C Raleigh "Political marginalization, climate change, and conflict in African Sahel states" (2010) 12 International Studies Review 69-86; C Raleigh \& H Urdal "Climate change, environmental degradation and armed conflict" (2007) 26:6 Political Geography 674-694; OM Theisen "Blood and soil? Resource scarcity and internal armed conflict revisited" (2008) 45:6 Journal of Peace Research $801-818$.

${ }^{27}$ United Nations Security Council Press Statement (20-07-20I I) SC/I 0332 http://www.un.org/News/Press/docs/20I l/scl 0332.doc.htm (accessed 04-02-20 I3).

${ }^{28}$ The terminology with regard to environmentally induced migration is varying and inconsistent and creates conflicts of a legal nature when it comes to the question as to whether or not a person can be classified as a refugee with the legal consequences of international refugee law. See K Warner, M Hamza, A Oliver Smith, F Renaud \& A Julca "Climate change, environmental degradation and migration" (2010) 55 Natural Hazards 693; W Kälin \& N Schrepfer "Protecting people crossing borders in the context of climate change. Normative gaps and possible approaches" (2012) Legal and Protection Policy Research Series http://www.unhcr.org/protect ( $14-02-2013) 28$.

${ }^{29}$ Foresight Migration and global environmental change 20 / I: Final project report (201 I).

${ }^{30} \mathrm{~J}$ Barnett \& M Webber "Migration as adaptation: Opportunities and limits" in J McAdam (ed) Climate change and displacement: Multidisciplinary perspectives (20 I0) 37-56.

${ }^{31}$ For a focus on climate-induced migration from Africa to Europe see $\mathrm{G}$ White Climate change and migration: Security and borders in a warming world (201 I).

32 Internal Displacement Monitoring Centre Displacement due to natural hazard-induced disasters, Global estimates for 2009-2010 (201 I).

${ }^{33}$ R Black, WN Adger, NW Arnell, S Dercon, A Geddes \& D Thomas "The effect of environmental change on human migration" (20 I I) 2I Global Environmental Change S3-SII. ${ }^{34}$ P Tschakert \& R Tutu "Solastalgia: Environmentally induced distress and migration among Africa's poor due to climate change" in T Afifi \& J Jäger (eds) Environment, Migration and Social Vulnerability (20 I0) 57-72; Internal Displacement Monitoring Centre Displacement due to natural hazard-induced disasters, Global estimates for 2009-2010 (201 I).

35 US National Intelligence Council "Effects of future climate change on cross-border migration in North Africa and India" (2010) 36 Population and Development Review 408-4I2.

${ }^{36}$ C Tomuschat "Risk and security in international law" in HP Hestermeyer, D König, N MatzLück, V Röben, A Seibert-Fohr, PT Stoll \& S Vöneki (eds) Coexistence, cooperation and solidarity: Liber Amicorum Rüdiger Wolfrum (20I2) 1283.

${ }^{37} \mathrm{~N}$ Schrijver "The impact of climate change: Challenges for international law" in U Fastenrath, R Geiger, DE Kahn, A Paulus, S von Schorlemer \& C Fedder (eds) From bilateralism to community interest - Essays in honour of Judge Bruno Simma (201 I) 1285.

${ }^{38}$ Case concerning Pulp Mills on the River Uruguay (Argentina v. Uruguay) International Court of Justice (20-04-20 I0) General List No. 135. 
${ }^{39}$ For an overview of legal issues relevant to climate change see for example J Brunnée, S Goldberg, R Lord QC \& L Rajamani "Overview of legal issues relevant to climate change" in R Lord, S Goldberg, L Rajamani \& J Brunnée Climate change liability (20 I2).

${ }^{40}$ For further details see R Rayfuse and SV Scott "Mapping the impact of climate change on international law" in R Rayfuse \& SV Scott (eds) International law in the era of climate change (20।2) 3-25.

${ }^{41}$ OC Ruppel \& K Ruppel-Schlichting "Climate change and human security: Relevant for regional integration in SADC?" in T Hartzenberg, G Erasmus \& A Du Pisani (eds) Monitoring regional integration in Southern Africa 201/ Yearbook for Regional Integration (2012) 46.

${ }^{42}$ See J Spier Shaping the law for global crises (2012) 49.

${ }^{43}$ B Kingsbury, N Krisch \& RB Stewart "The emergence of global administrative law" (20042005) 68 Law and Contemporary Problems 16.

${ }^{44}$ The 1987 Montreal Protocol introduced a series of effective steps to phase out the global production and consumption of ozone-depleting substances in the 1980s. The Protocol and successor agreements are not only regarded as highly successful examples of international environmental regulatory cooperation, there are also lessons to be learned from the ozone layer experience in dealing with climate change. The Montreal Protocol has made a substantial commitment to climate goals, and there are substantial proposals on the way to increase this. Having phased out 97 per cent of almost 100 ozone-depleting substances (ODSs) it placed the ozone layer on a path to recovery. "Because many ODSs are also potent greenhouse gases (GHGs), their phase-out under the Montreal Protocol has provided an often overlooked bonus for climate mitigation: by the end of the decade, the Montreal Protocol will have done more to mitigate climate change than the initial Kyoto Protocol reduction target, reducing emissions in terms of carbon dioxide ('CO2'), equivalent to I 35 billion tonnes between 1990 and 2010 and delayed climate impacts - including abrupt and irreversible impacts - by about 12 years" Cf. http://www.igsd.org/montreal/index.php (also for further references) (accessed 25-II-20 I2). 45 The following two forthcoming publications attempt to provide a scientific contribution towards assessing the different legal and regulatory regimes: OC Ruppel, C Roschmann \& $\mathrm{K}$ Ruppel-Schlichting (eds) Climate change: Legal responses and global responsibility (forthcoming 20 I3); OC Ruppel, C Roschmann \& K Ruppel-Schlichting (eds) Climate change and global governance: International regimes in a changing environment (forthcoming 20I3).

${ }_{46}$ This section is largely based on OC Ruppel "International legal climate change regimes and climate finance from a Southern African perspective" in OC Ruppel \& K Ruppel-Schlichting (eds) Environmental law and policy in Namibia. Towards making Africa the tree of life (2013) 287-308.

${ }^{47}$ J Depledge \& F Yamin "The global climate regime: A defence" in D Helm \& C Hepburn (eds) The economics and politics of climate change (2009) 433-453.

${ }^{48} \mathrm{Cf}$. for more details AMCEN Addressing climate change challenges in Africa; A practical guide towards sustainable development (201 I).

${ }^{49}$ United Nations Framework Convention on Climate Change "An introduction to the United Nations Framework Convention on Climate Change (UNFCCC) and the Kyoto Protocol" (20 I I) http://unfccc.int/files/press/backgrounders/application/pdf/unfccc_and_kyoto_protocol.pdf (accessed 17-02-20/3).

50 United Nations Framework Convention on Climate Change "The need for mitigation" (2009) http://unfccc.int/files/press/backgrounders/application/pdf/press_factsh_mitigation.pdf (accessed 17-02-2013).

${ }^{51}$ United Nations Framework Convention on Climate Change "The need for adaptation" (2010) http://unfccc.int/files/press/application/pdf/adaptation_fact_sheet.pdf (accessed 17-022013).

${ }^{52}$ L Boisson de Chazourne "United Nations Framework Convention on Climate Change" (2008) http://untreaty.un.org/cod/avl/pdf/ha/ccc/ccc_e.pdf (accessed 17-02-20 I 3).

${ }^{53}$ The Bali Road Map emerged from the 2007 Bali Climate Change Conference and includes the Bali Action Plan (Decision I/CP.I3), which launched a "comprehensive process to enable 
the full, effective and sustained implementation of the Convention through long-term cooperative action" along with a number of other decisions and resolutions.

${ }^{54}$ Agreed upon by the UNFCCC Conference of the Parties, in Copenhagen on 18 December 2009 by way of Decision 2/CP.I5.

${ }^{55}$ Decision I/CP. 16 The Cancun Agreements: Outcome of the work of the Ad Hoc Working Group on Long-term Cooperative Action under the Convention.

${ }^{56}$ Decision I/CMP.6 The Cancun Agreements: Outcome of the work of the Ad Hoc Working Group on Further Commitments for Annex I Parties under the Kyoto Protocol at its fifteenth session; and Decision 2/CMP.6 The Cancun Agreements: Land use, land-use change and forestry.

${ }^{57}$ Intergovernmental Panel on Climate Change "Tenth anniversary brochure" (200I) http://www.ipcc.ch/pdf/ I Oth-anniversary/anniversary-brochure.pdf (accessed 17-02-20 I3).

${ }^{58}$ See Article 3(4) of the Kyoto Protocol.

${ }^{59}$ Cf. IPCC on Working groups / Task Force

http://www.ipcc.ch/working_groups/working_groups.shtml (accessed 17-02-2013).

${ }^{60}$ Cf. https://www.ipcc-wgl .unibe.ch/ (accessed 17-02-20 I3).

${ }^{61}$ Cf. http://www.ipcc.ch/working_groups/working_groups.shtml (accessed 17-02-2013).

${ }^{62}$ Cf. http://ipcc-wg2.gov/index.html (accessed 17-02-2013)

${ }^{63} \mathrm{Cf}$. http://www.ipcc.ch/working_groups/working_groups.shtml (accessed 17-02-2013).

${ }^{64}$ Cf. http://www.ipcc-wg3.de/ (accessed 17-02-2013).

${ }^{65}$ J Mathiason \& MP Bhandari "Getting the facts right: The Intergovernmental Panel on Climate Change and the new climate regime" (2010) I:I Journal of International Organization Studies $57-7$ I.

${ }^{66}$ SR Weart "The evolution of international cooperation in climate science" (2012) 3:1 Journal of International Organization Studies 4 I-59.

${ }^{67}$ SR Weart Never at war: Why democracies will not fight one another (1998) 61.

${ }^{68}$ SR Weart "The evolution of international cooperation in climate science" (2012) 3:1 Journal of International Organization Studies 4I-59.

${ }^{69}$ SR Weart Never at war: Why democracies will not fight one another (1998) 262-267.

70 SR Weart "The evolution of international cooperation in climate science" (2012) 3:I Journal of International Organization Studies 55-57.

${ }^{71}$ Cf. http://www.nobelprize.org/nobel_prizes/peace/laureates/2007/ (accessed 04-03-20 I3).

72 M Kowarsch "Wie neutral ist die Klimawissenschft? Über die Aktuellen Vorwürfe an den IPCC und die Klimaforschung" (20I0) http://dialog.hfph.mwn.de/Members/m_kowarsch/wieneutral-ist-die-klimawissenschaft/ (accessed 17-02-2013).

${ }^{73}$ J Mathiason \& MP Bhandari "Getting the facts right: The Intergovernmental Panel on Climate Change and the new climate regime" (2010) I:I Journal of International Organization Studies 57.

${ }^{74}$ Because of doubts regarding the IPCC results US Congress has mandated a large group of scientists and representatives of the private industry in 2008 to verify the IPCC results. The outcome can be accessed at http://online.wsj.com/article/SB I 000 | 42405274870469 | 30457525469 |763608402.html?mod= WSI_hps_SECONDTopStories (accessed 17-02-2013).

${ }^{75}$ Cf. http://www.ipcc.ch/activities/activities.shtml (accessed I4-02-20I2).

${ }^{76}$ R Pachauri, "Speech by Rajendra K. Pachauri, Chairman, IPCC at the Opening Ceremony of the Scoping Meeting for the Fifth Assessment Report (AR5) of the IPCC" (I3-07-2009) http://www.ipcc.ch/graphics/speeches/rkp-speech-venice-07-2009.pdf (accessed 20-08-20 I0). 77 InterAcademy Council "IAC in brief" (2013) http://www.interacademycouncil.net/23450/27799.aspx (accessed 17-02-20 I3).

${ }^{78}$ KE Davis, B Kingsbury, S Engle Merry "Indicators as a technology of global governance" (2012) 46:I Law \& Society Review.

${ }^{79}$ Cf. http://www.ipcc.ch/organization/organization.shtml\#.URelrmhpvos (accessed 17-02-2013). 
${ }^{80}$ MJ Mathiason \& MP Bhandari "Getting the facts right: The Intergovernmental Panel on Climate Change and the new climate regime" (2010) I:I Journal of International Organization Studies 58.

${ }^{81}$ UN Secretary-General Ban Ki-moon's remarks at the Sorensen Distinguished Lecture on the United Nations at the Council on Foreign Relations, New York ( I I-02-20 I3) http://www.un.org/sg/statements/index.asp?nid=6595 (accessed I5-02-20 I3).

${ }^{82}$ SV Scott "The securitization of climate change in world politics: How close have we come and would full securitization enhance the efficacy of global climate change policy?" (20I2) 21:3 Review of European Community and International Environmental Law 220-230.

${ }^{83}$ Speech by NATO Secretary General Anders Fogh Rasmussen on emerging security risks, Lloyd's of London ( I October 2009) http://www.nato.int/cps/en/natolive/opinions_57785.htm (accessed 17-02-2013).

${ }^{84}$ United Nations Security Council Press Statement (20-07-20I I) SC/I 0332

http://www.un.org/News/Press/docs/201 I/scl 0332.doc.htm (accessed 04-02-2013).

${ }^{85}$ United Nations Security Council Press Statement (20-07-20I I) SC/I0332

http://www.un.org/News/Press/docs/20 I I/sc l 0332.doc.htm (accessed 04-02-20 I3).

${ }^{86}$ United Nations Security Council Press Statement (20-07-20I I) SC/I 0332

http://www.un.org/News/Press/docs/20 I I/scl 0332.doc.htm (accessed 04-02-20 I3).

${ }^{87}$ SV Scott "The securitization of climate change in world politics: How close have we come and would full securitization enhance the efficacy of global climate change policy?" (20I2) 21:3

Review of European Community and International Environmental Law 222.

${ }^{88}$ Statement by the President of the Security Council (20-07-20 I I) UN Doc S/PRST/20 I I/I 5.

${ }^{89}$ UN Charter Article 27.3. Although not explicitly stated in the Charter, it has become accepted that this vote may include abstentions by permanent members.

${ }^{90}$ AD Koroma "Solidarity: Evidence of an emerging international legal principle" in HP

Hestermeyer, D König, N Matz-Lück, V Röben, A Seibert-Fohr, PT Stoll \& S Vöneki (eds)

Coexistence, cooperation and solidarity: Liber Amicorum Rüdiger Wolfrum (2012) 103-129.

${ }_{91}$ Article 25.

${ }^{92}$ Article 39.

${ }^{93}$ Article 41.

${ }^{94}$ Article 42.

${ }^{95}$ See for example M Wood "The UN Security Council and international law" Hersch Lauterpacht Memorial Lecture, Cambridge (08-I I-2006)

http://www.lcil.cam.ac.uk/Media/lectures/pdf/2006_hersch_lecture_2.pdf (accessed 17-02-20 I 3).

${ }^{96}$ Report of the Secretary-General on the Work of the Organization, document A/54/I, at 48 (31-08-1999).

${ }^{97}$ AD Koroma "Solidarity: Evidence of an emerging international legal principle" in HP

Hestermeyer, D König, N Matz-Lück, V Röben, A Seibert-Fohr, PT Stoll \& S Vöneki (eds)

Coexistence, cooperation and solidarity: Liber Amicorum Rüdiger Wolfrum (2012) 103-129.

${ }^{98} \mathrm{P}$ Thielbörger \& M Liburd "Haiti two years after the earthquake - A case for the responsibility to protect?" (2012) BOFAXE399E.

${ }^{99}$ Address by UN Under-Secretary-General and UNEP Executive Director Achim Steiner at UN Security Council Debate on the impact of climate change on maintaining international peace and security (20-07-20I I)

http://www.unep.org/Documents.Multilingual/Default.Print.asp?DocumentID=2646\&ArticleID=8 $8|7 \&|=e n$ (accessed 17-02-20|3).

${ }^{100}$ Cf. with further references SV Scott "The securitization of climate change in world politics: How close have we come and would full securitization enhance the efficacy of global climate change policy?" (2012) 21:3 Review of European Community and International Environmental Law 221 .

101 See R Taureck "Securitization theory and securitization studies" (2006) 9:1 Journal of International Relations and Development 55. 
102 SV Scott "The Securitization of climate change in world politics: How close have we come and would full securitization enhance the efficacy of global climate change policy?" (2012) 21:3 Review of European Community and International Environmental Law 221.

${ }^{103}$ N Schrijver "The impact of climate change: Challenges for international law" in U Fastenrath, R Geiger, DE Kahn, A Paulus, S von Schorlemer \& C Fedder (eds) From bilateralism to community interest - Essays in honour of Judge Bruno Simma (201 I) 1285.

${ }^{104}$ Permanent Court of Arbitration, The Island of Palmas Case (or Miangas) Unites States of America $v$ The Netherlands Award of the Tribunal (04-04-1928), XI UNRIAA 838.

105 TW Pogge "International relations as a modus vivendi" (1987) 81 American Proceedings of International Law 429.

${ }^{106}$ For an interesting exploration see C Voigt "State responsibility for climate change damages" (2008) 77 Nordic Journal for International Law I.

${ }^{107}$ TW Pogge "International relations as a modus vivendi" (1987) 81 American Proceedings of International Law 436.

${ }^{108}$ See the Preamble to the UNFCCC.

109 N Schrijver "The impact of climate change: Challenges for international law" in U Fastenrath, R Geiger, DE Kahn, A Paulus, S von Schorlemer \& C Fedder (eds) From bilateralism to community interest - Essays in honour of Judge Bruno Simma (201 I) 1278.

110 AD Koroma "Solidarity: Evidence of an emerging international legal principle" in HP Hestermeyer, D König, N Matz-Lück, V Röben, A Seibert-Fohr, PT Stoll \& S Vöneki (eds)

Coexistence, cooperation and solidarity: Liber Amicorum Rüdiger Wolfrum (20 I2) 108.

"I' K Vasak "Pour une troisième generation des droits de l'homme" in C Swinarski (ed) Studies and essays on international humanitarian law and Red Cross principles (1984) 839.

112 United Nations The Millennium Development Goals Report 2012 (2012).

${ }^{113}$ Food and Agriculture Organization of the United Nations, World Food Programme \& International Fund for Agricultural Development The state of food insecurity in the world $20 / 2$ (20I2).

114 See http://hdr.undp.org/en/data/map/ (accessed I4-02-2013).

115 United Nations The Millennium Development Goals Report 2012 (2012).

116 UNICEF \& WHP Joint Monitoring Programme (JMP) for Water Supply and Sanitation.

Progress on sanitation and drinking-water (20I2).

117 Office of the United Nations High Commissioner for Human Rights and UN-HABITAT "The right to adequate housing" (2009) Fact Sheet No. 21

http://www.ohchr.org/Documents/Publications/FS2 I_rev_I_Housing_en.pdf (accessed I4-0220/3).

118 United Nations Secretary-General's Advisory Group on Energy and Climate Change (AGECC), Energy for a sustainable future (20I0).

119 UIS/UNESCO Institute for Statistics "Adult and youth literacy" (20I2) UIS Factsheet No. 20 http://www.uis.unesco.org/FactSheets/Documents/fs20-literacy-day-20I2-en-v3.pdf (accessed |4-02-20|3).

${ }^{120}$ See http://www.ilo.org/global/topics/child-labour/lang--en/index.htm (accessed I4-02-20 I3).

${ }^{121}$ OW Pedersen "The Janus-head of human rights and climate change: Adaptation and mitigation" (20/2) http://www.nccr-

climate.unibe.ch/conferences/climate_economics_law/papers/Pedersen_OleW.pdf, 29pp (accessed 31-12-2012) 28.

122 S Mclnerney-Lankford "Climate change and human rights: An introduction to legal issues" (2009) 33 Harvard Environmental Law Review 43I-438.

${ }^{123}$ International Council on Human Rights Policy Climate change and human rights: A rough guide (2008).

${ }^{124}$ JH Knox "Climate change and human rights law" (2009) 50:I Virginia Journal of International LaW.

${ }^{125}$ W Kälin \& N Schrepfer "Protecting people crossing borders in the context of climate change. Normative gaps and possible approaches" (2012) http://www.unhcr.org/protect (accessed I402-2013) 17. 
${ }^{126}$ For a detailed analysis of this concept see J Delbrück "The international obligation to cooperate - An empty shell or a hard law principle of international law? - A critical look at a much debated paradigm of modern international law" in HP Hestermeyer, D König, N MatzLück, V Röben, A Seibert-Fohr, PT Stoll \& S Vöneki (eds) Coexistence, cooperation and solidarity: Liber Amicorum Rüdiger Wolfrum (2012) 3-16.

127 Section 15 of the Resolution on the enhancement of international cooperation in the field of human rights see A/HRC/I9/L.I3/Rev.I (20-03-20I2) http://daccess-ddsny.un.org/doc/RESOLUTION/LTD/G I 2/I24/35/PDF/G I 2 I 2435.pdf?OpenElement (accessed 04-03-20 I3).

${ }^{128}$ OC Ruppel "Climate change and human vulnerability: Law and policy" (2010) Unpublished paper presented at an expert workshop on /dentifying priorities for climate change, organised by the Human Rights and Documentation Centre (HRDC) of the University of Namibia (UNAM) in cooperation with the Tyndall Centre for Climate Change (University of Oxford) held at the Safari Court Conference Centre, Windhoek (09-03-20 I0).

129 Three months after being ratified by 10 parties. As of 12 February 2013 the Protocol had 42 signatories and 10 parties. See

http://treaties.un.org/Pages/ViewDetails.aspx?src=TREATY\&mtdsg_no=IV-3-

a\&chapter=4\&lang=en (accessed 12-02-2013).

130 UN Doc A/HRC/7/23 (28-03-2008)

http://ap.ohchr.org/documents/E/HRC/resolutions/A_HRC_RES_7_23.pdf (accessed I3-02-

20I3).

131 UN Doc A/HRC/I0/6 I (I5-0I-2009) http://daccess-dds-

ny.un.org/doc/UNDOC/GEN/G09/I03/44/PDF/G09I0344.pdf?OpenElement (accessed I2-022013).

132 UN Doc A/HRC/RES/19/10 (19-04-2012) http://daccess-ddsny.un.org/doc/RESOLUTION/GEN/G I 2/| 3 |/59/PDF/G I 13 | 159.pdf?OpenElement (accessed |2-02-2013).

${ }^{133} \mathrm{~W}$ Scholtz "The promotion of regional environmental security and Africa's common position on climate change" (2010) I0 African Human Rights Law Journal I-25.

${ }^{134}$ OC Ruppel \& S van Wyk "The effects of climate change on human security and human rights in Africa" (201 I) China Monitor I0-16.

135 Decision I/CP. 16 http://unfccc.int/resource/docs/20 I 0/cop I 6/eng/07a0 I.pdf\#page=2 (accessed I2-02-2013).

${ }^{136}$ E Cameron \& M Limon "Restoring the climate by realizing rights: The role of the international human rights system" (2012) 21:3 Review of European Community and International Environmental Law 204.

${ }^{137}$ For further information see International Council on Human Rights Policy Climate change and human rights: A rough guide (2008) 5.

${ }^{138}$ For a detailed analysis see $E$ Cameron \& $M$ Limon "Restoring the climate by realizing rights: The role of the international human rights system" (2012) 21:3 Review of European Community and International Environmental Law 204-219.

${ }^{139}$ E Cameron \& M Limon "Restoring the climate by realizing rights: The role of the international human rights system" (2012) 21:3 Review of European Community and International Environmental Law $2 \mid 4$.

${ }^{140} \mathrm{D}$ Shelton "The legal status of normative pronouncements of human rights treaty bodies" in HP Hestermeyer, D König, N Matz-Lück, V Röben, A Seibert-Fohr, PT Stoll \& S Vöneki (eds) Coexistence, cooperation and solidarity: Liber Amicorum Rüdiger Wolfrum (20I2) 574.

${ }^{14 \mid}$ See D Hodgkinson \& L Young '“In the face of looming catastrophe': A convention for climate change displaced persons" (2012)

http://www.ccdpconvention.com/documents/Climate\%20change\%20displacement\%20treaty\%20 proposal.pdf (accessed 05-02-20।2).

142 Article I.A.(2). 195 I Convention Relating to the Status of Refugees. 
${ }^{143}$ W Kälin \& N Schrepfer "Protecting people crossing borders in the context of climate change. Normative gaps and possible approaches" (2012) http://www.unhcr.org/protect (accessed I402-20।3) 42.

${ }^{144}$ W Kälin \& N Schrepfer "Protecting people crossing borders in the context of climate change. Normative gaps and possible approaches" (2012) http://www.unhcr.org/protect (accessed I402-2013) 42.

${ }^{145}$ W Kälin \& N Schrepfer "Protecting people crossing borders in the context of climate change. Normative gaps and possible approaches" (2012) http://www.unhcr.org/protect (accessed I402-20।3) 58.

${ }^{146}$ Benin, Burkina Faso, Central African Republic, Chad, Gabon, Gambia, Guinea-Bissau, Lesotho, Mali, Nigeria, Niger, Sierra Leone, Swaziland, Togo, Uganda and Zambia.

${ }_{147}$ Article I ( k) of the Kampala Convention.

${ }^{148}$ See RK Craig Comparative ocean governance - Place-based protections in an era of climate change (20I2) 54.

149 IPCC Working Group / Contribution to the Fourth Assessment Report of the Intergovernmental Panel on Climate Change. Summary for policymakers, technical summary and frequently asked questions (2007) I3.

${ }^{150}$ RK Craig Comparative ocean governance - Place-based protections in an era of climate change (20I2) 53.

${ }^{151}$ C Le Quéré, T Takahashi, ET Buitenhuis, C Rödenbeck \& SC Sutherland "Impact of climate change and variability on the global oceanic sink of CO2" (2010) 24 Global Biogeochemical Cycles I.

152 D Freestone "Climate change and the oceans" (2009) 4 Carbon and Climate Law Review 383.

${ }^{153}$ For an in-depth discussion see R Rayfuse "Climate change and the law of the sea" in R Rayfuse \& SV Scott (eds) International law in the era of climate change (20 I2) 147-174.

${ }^{154}$ Such as the 1954 International Convention for the Prevention of Pollution of the Sea by Oil; the 1972 London Convention on the Prevention of Marine Pollution by Dumping of Wastes and other Matter; or the 1973 International Convention for the Prevention of Pollution from Ships (MARPOL).

${ }^{155}$ Such as the 1992 United Nations Convention on Biological Diversity.

${ }^{156}$ RK Craig Comparative ocean governance - Place-based protections in an era of climate change (20I2) 71 .

${ }^{157}$ As of 31 January 2013. Cf.

http://www.un.org/Depts/los/reference_files/chronological_lists_of_ratifications.htm. The United States have not acceded to the convention. It is argued that accession "would expose the United Sates to international lawsuits (including suits based on U.S. contributions to global climate change) that would harm its environmental, economic and military interests". Cf. S Groves "Accession to the U.N. Convention on the Law of the Sea would expose the U.S. to baseless climate change lawsuits" (20 I2) Backgrounder No. 2660

http://report.heritage.org/bg2660 (accessed 08-02-20I3).

${ }^{158}$ For a detailed discussion see J Lisztwan "Stability of marine boundary agreements" (201 I) 37: I The Yale Journal of International Law I53-200.

${ }^{159}$ It has for example been estimated that a one-meter rise in sea levels will affect I 45 million people. Cf. D Anthoff, R Nicholls, R Tol \& A Vafeidis "Global and Regional exposure to large rises in sea-level: A sensitivity analysis" (2006) Tyndall Centre Working Paper No. 90.

Displacement and migration due to sea level rise are thus further pressing challenges as coastal populations are exposed to the risk of land loss due to inundation and erosion. See J Barnett \& M Webber "Accommodating migration to promote adaptation to climate change" Background Paper to the 2010 World Development Report, World Bank Policy Research Working Paper 5270 http://elibrary.worldbank.org/docserver/download/5270.pdf?expires=| 359468830\&id=id\&accna me=guest\&checksum=802 I FB77228A70DFEC3AA8 I 8FFB5206B (accessed 07-02-20 I3). 
160 See M Gagain "Climate change, sea level rise, and artificial islands: Saving the Maledives' statehood and maritime claims through the 'Constitution of the Oceans"' (20I2) 23:I Colorado Journal of International Environmental Law and Policy 77-120.

161 The other four being the atmosphere, Antarctica, and outer space.

162 International Maritime Organization "IMO and the environment" (201 I)

http://www.imo.org/ourwork/environment/documents/imo\%20and\%20the\%20environment\%20 20I I.pdf (accessed 0 I-02-20 I3).

${ }^{163}$ See P Kaluza, A Kölzsch, MT Gastner \& B Blasius "The complex network of global cargo ship movements" (2010) Journal of the Royal Society.

164 See United Nations General Assembly Oceans and the Law of the Sea Report of the Secretary General (3I-08-20 I2) A/67/79/Add. I http://daccess-dds-

ny.un.org/doc/UNDOC/GEN/N I 2/478/4 I/PDF/N I 24784 I.pdf?OpenElement (accessed 0 I-022013).

${ }^{165}$ For this and the following observations on maritime armament see J Grebe and C Schwarz

"Die maritime Aufrüstung der Schwellenländer. Strategische und friedenspolitische

Implikationen" in M Johannsen, B Schoch, C Hauswedell T Debiel \& C Fröhlich (eds)

Friedensgutachten 201/ (2011) 316-327.

166 J Grebe \& C Schwarz "Die maritime Aufrüstung der Schwellenländer. Strategische und friedenspolitische Implikationen" in M Johannsen, B Schoch, C Hauswedell T Debiel \& C Fröhlich (eds) Friedensgutachten 20/ / (201 I) 316-327.

${ }^{167}$ Available at http://www.defesa.gov.br/projetosweb/estrategia/arquivos/estrategia_defesa_nacional_ingles.pdf (accessed 29 January 2013).

${ }^{168}$ D Flemes \& A Costa Vaz "Security policies of India, Brazil and South Africa - Regional security contexts as constraints for a common agenda" (20II) GIGA Working Papers No. 160 http://www.giga-hamburg.de/dl/download.php?d=/content/publikationen/pdf/wp I 60_flemesvaz.pdf (accessed 29-0I-2013) I6.

169 According to the website of the South African Navy at http://www.navy.mil.za/aboutus/role/page2.htm\#0I (accessed 29-0I-20l3).

${ }^{170} \mathrm{C}$ Ezeanya "The need for a sea change in Africa's coastal

laws" (2013) Think Africa Press (22-0 I-20l3) http://thinkafricapress.com/economy/searchindependence-african-coastal-waters (accessed 28-0I-20।3).

${ }^{171}$ Available at http://www.au.int/en/content/revised-african-maritime-transport-charter (accessed 28 January 20I3).

172 T Houser "Copenhagen, the accord, and the way forward" (2010) Policy Brief I0-5 Peterson Institute for International Economics

http://www.piie.com/publications/interstitial..fm?ResearchID=I 508 (accessed 17-02-20 I3).

${ }^{173}$ Cf T Miles "WTO risks future by keeping Doha alive" (3I-I2-20II)

http://www.taipeitimes.com/News/editorials/archives/20 I I/I2/31/2003522031 (accessed 17-022013).

174 TW Pogge "Keynote address: Poverty, climate change, and overpopulation" (2010) 38 Georgia Journal of International and Comparative Law 534.

${ }^{175}$ OC Ruppel \& K Ruppel-Schlichting "Climate change and human security: Relevant for regional integration in SADC?" in T Hartzenberg, G Erasmus \& A Du Pisani (eds) Monitoring regional integration in Southern Africa 201/ Yearbook for Regional Integration (2012) 46. 175 See I Spier Shaping the law for global crises (2012).

176 OC Ruppel \& K Ruppel-Schlichting "Climate change and human security: Relevant for regional integration in SADC?" in T Hartzenberg, G Erasmus \& A Du Pisani (eds) Monitoring regional integration in Southern Africa $201 /$ Yearbook for Regional Integration (20 I2) 32-7I. 177 OC Ruppel \& K Ruppel-Schlichting "Climate change and human security: Relevant for regional integration in SADC?" in T Hartzenberg, G Erasmus \& A Du Pisani (eds) Monitoring regional integration in Southern Africa $201 /$ Yearbook for Regional Integration (20 I2) 32-7I. 
${ }^{178} \mathrm{R}$ Moncel \& $\mathrm{H}$ van Asselt "All hands on deck! Mobilizing climate change action beyond the UNFCCC" (2012) 21:3 Review of European Community and International Environmental Law 169.

${ }^{179}$ R Wolfrum "Solidarity amongst states: An emerging structural principle of international law" in PM Dupuy, B Fassbender, MN Shaw \& KP Sommermann (eds) Völkerrecht als Weltordnung - Common values in international law: Essays in honour of Christian Tomuschat (2006) 1097.

${ }^{180} \mathrm{HP}$ Hestermeyer "Reality or aspiration? - Solidarity in international environmental and world trade law" in HP Hestermeyer, D König, N Matz-Lück, V Röben, A Seibert-Fohr, PT Stoll \& S Vöneki (eds) Coexistence, cooperation and solidarity: Liber Amicorum Rüdiger Wolfrum (2012) 57.

${ }^{181}$ See for example M Doelle "Climate change and the WTO: Opportunities to motivate state action on climate change through the World Trade Organization" (2004) I3:I Review of European Community and International Environmental Law 85; GC Hufbauer, S Charnovitz \& J Kim Global warming and the world trading system (2009); L Tamiotti Trade and climate change: A report by the United Nations Environment Programme and the World Trade Organization (2009); T Epps \& A Green Reconciling trade and climate: How the WTO can help address climate change (20 I0); F Zelli \& H van Asselt "The overlap between the UN climate regime and the World Trade Organization: Lessons for post-20I 2 climate governance" in F Biermann, P Pattberg \& F Zelli (eds) Global climate governance beyond 2012: Architecture, agency and adaptation (2010) 79.

182 Cf. R Eckersley "The big chill: The WTO and multilateral environmental agreements" (2004) 4:2 Global Environmental Politics 24.

${ }_{183}^{18}$ A Green "Trade rules and climate change subsidies" (2006) 5:3 World Trade Review 38I; SZ Bigdeli "Will the 'friends of climate' emerge in the WTO? The prospects of applying the 'fisheries subsidies' model to energy subsidies" (2008) 2:I Carbon and Climate Law Review 78. 184 Paragraph 24 of the Pittsburgh Summit Declaration http://www.g20.utoronto.ca/2009/2009communique0925.html (accessed 17-02-2013). 185 In November 2012, however, the European Commission has proposed deferring the application of the scheme to flights into and out of Europe until after the ICAO General Assembly in autumn 2013 as a gesture of goodwill in support of an international solution.

186 K Kulovesi "Addressing sectoral emission outside the United Nations Framework Convention on Climate Change: What roles for multilateralism, minilateralism and unilateralism" (2012) 21:3 Review of European Community and International Environmental Law 220-230. ${ }^{187}$ For an overview of legal arguments in this regard, see K Kulovesi "Make your own special song even if nobody else sings along: International aviation emissions and the EU Emissions Trading Scheme" (20I I) 2:4 Climate Law 535.

188 J Scott \& L Rajamani "EU climate change unilateralism" (2012) 23:2 European Journal of International Law 469.

189 See

http://www.imo.org/MediaCentre/resources/Pages/Greenhouse\%20gas\%20emissions.aspx (accessed 05-02-2013).

190 See http://ec.europa.eu/clima/policies/transport/shipping/index_en.htm (accessed 05-022013)

191 J Delbrück "The international obligation to cooperate - An empty shell or a hard law principle of international law? - A critical look at a much debated paradigm of modern international law" in HP Hestermeyer, D König, N Matz-Lück, V Röben, A Seibert-Fohr, PT Stoll \& S Vöneki (eds) Coexistence, cooperation and solidarity: Liber Amicorum Rüdiger Wolfrum (2012) 15.

${ }^{192}$ C Schreuer "State sovereignty and the duty of states to cooperate - Two incompatible notions?" in J Delbrück (ed) International law of cooperation and state sovereignty, Proceedings of an international symposium of the Kiel Walther Schücking Institute of International Law (200I) 177. 
193 Similarly see E Morgera "Bilateralism at the service of community interests? Non-judicial enforcement of global public goods in the context of global environmental law" (2012) 23:3 European Journal of International Law.

${ }^{194}$ K Kulovesi "Addressing sectoral emission outside the United Nations Framework Convention on Climate Change: What roles for multilateralism, minilateralism and unilateralism" (2012) 21:3 Review of European Community and International Environmental Law 220-230.

${ }^{195}$ C Tietje "The duty to cooperate in international economic law and related areas" in J Delbrück (ed) International law of cooperation and state sovereignty, Proceedings of an international symposium of the Kiel Walther Schücking Institute of International Law (200 I).

196 J Delbrück "The international obligation to cooperate - An empty shell or a hard law principle of international law? - A critical look at a much debated paradigm of modern international law" in HP Hestermeyer, D König, N Matz-Lück, V Röben, A Seibert-Fohr, PT Stoll \& S Vöneki (eds) Coexistence, cooperation and solidarity: Liber Amicorum Rüdiger Wolfrum (2012) 9.

${ }^{197}$ R Leal-Arcas "On climate migration and international trade" (2012) 6:3 \& 4 Vienna Journal of International Constitutional Law 4I 0-440.

198 R Leal-Arcas "On climate migration and international trade" (2012) 6:3 \& 4 Vienna Journal of International Constitutional Law 410-440 with further references; L Westra Environmental justice and the rights of ecological refugees (2009); O Stokke (ed) Implementing the climate regime: International compliance (2005).

$199 \mathrm{http}: / / \mathrm{ww}$.clubofrome.org/? $\mathrm{p}=703$ (accessed 17-02-20 I3).

$200 \mathrm{http}: / / \mathrm{www}$.clubofrome.org/?p=703 (accessed 17-02-20 I3).

201 This section is largely based on OC Ruppel "The WTO Chairs Programme and the role of world trade and economic development for regional integration, the reduction of poverty and the promotion of economic, social and cultural rights in Africa" (2012) I Recht in Africa I43156.

${ }^{202}$ Cf. OC Ruppel "The SADC Tribunal, regional integration and human rights: Major challenges, legal dimensions and some comparative aspects from the European legal order" (2009) 2 Recht in Afrika.

${ }^{203}$ OC Ruppel "Regional economic communities and human rights in East and Southern Africa" in A Bösl \& J Diescho (eds) Human rights in Africa 275-318.

${ }^{204}$ OC Ruppel \& K Ruppel-Schlichting "Climate change and human security: Relevant for regional integration in SADC?" in T Hartzenberg, G Erasmus \& A Du Pisani (eds) Monitoring regional integration in Southern Africa 201/ Yearbook for Regional Integration (2012) 41. ${ }^{205}$ AG Pillay "The optional protocol to the International Covenant on Economic, Social and Cultural Rights" in C Roschmann \& P Wendoh (eds) Conference Report: Economic rights as human rights (2009).

206 TW Pogge "Are we violating the human rights of the world's poor?" (20I I) I4:2 Yale Human Rights and Development Law Journal 20.

207 TW Pogge "The incoherence between Rawls's theories of justice" (2004) 72 Fordham Law Review 1759.

${ }^{208}$ JA Garibaldi, M Araya \& G Edwards "Shaping the Durban Platform: Latin America and the Caribbean in a future high ambition deal" (2012) Policy Brief

http://www.intercambioclimatico.com/wp-content/uploads/Shaping-Durban-Platform_FinalApril_20 I2.pdf (accessed 17-02-20 I3).

209 TW Pogge "Keynote address: Poverty, climate change, and overpopulation" (2010) 38 Georgia Journal of International and Comparative Law 528.

${ }^{210}$ JB Davies, S Sandstrom, A Shorrocks \& EN Wolff "The world distribution of household wealth" (05-12-2006) http://www.iariw.org/papers/2006/davies.pdf (accessed 17-02-20I3). 211 TW Pogge "Keynote address: Poverty, climate change, and overpopulation" (2010) 38 Georgia Journal of International and Comparative Law 528.

212 EA Stanton "The tragedy of maldistribution: Climate, sustainability, and equity" (2012) 4 Sustainability 394-4II. 
213 T Koh "Is there a role for law in a world ruled by power?" in HP Hestermeyer, D König, N Matz-Lück, V Röben, A Seibert-Fohr, PT Stoll \& S Vöneki (eds) Coexistence, cooperation and solidarity: Liber Amicorum Rüdiger Wolfrum (2012) 1235-1239.

214 T Koh "Is there a role for law in a world ruled by power?" in HP Hestermeyer, D König, N Matz-Lück, V Röben, A Seibert-Fohr, PT Stoll \& S Vöneki (eds) Coexistence, cooperation and solidarity: Liber Amicorum Rüdiger Wolfrum (2012) 1237.

215 TW Pogge "International relations as a modus vivendi" (1987) 8I American Proceedings of International Law 430.

216 J Delbrück "The international obligation to cooperate - An empty shell or a hard law principle of international law? - A critical look at a much debated paradigm of modern international law" in HP Hestermeyer, D König, N Matz-Lück, V Röben, A Seibert-Fohr, PT Stoll \& S Vöneki (eds) Coexistence, cooperation and solidarity: Liber Amicorum Rüdiger Wolfrum (20I2) 4.

217 J Delbrück "The international obligation to cooperate - An empty shell or a hard law principle of international law? - A critical look at a much debated paradigm of modern international law" in HP Hestermeyer, D König, N Matz-Lück, V Röben, A Seibert-Fohr, PT Stoll \& S Vöneki (eds) Coexistence, cooperation and solidarity: Liber Amicorum Rüdiger Wolfrum (20।2) 5.

${ }^{218} \mathrm{R}$ Wolfrum in Rudolph Bernhardt (ed) Encyclopedia of Public International Law (EPIL) Vol. II (I995) 1242.

${ }^{219}$ See J Delbrück (ed) International law of cooperation and state sovereignty, Proceedings of an international symposium of the Kiel Walther Schücking Institute of International Law (200 I).

220 J Delbrück "The international obligation to cooperate - An empty shell or a hard law principle of international law? - A critical look at a much debated paradigm of modern international law" in HP Hestermeyer, D König, N Matz-Lück, V Röben, A Seibert-Fohr, PT Stoll \& S Vöneki (eds) Coexistence, cooperation and solidarity: Liber Amicorum Rüdiger Wolfrum $(2012) 13$.

${ }^{221}$ See C Schreuer "State sovereignty and the duty of states to cooperate - Two incompatible notions?" in I Delbrück (ed) International law of cooperation and state sovereignty, Proceedings of an international symposium of the Kiel Walther Schücking Institute of International Law (200I) 179.

222 J Delbrück "The international obligation to cooperate - An empty shell or a hard law principle of international law? - A critical look at a much debated paradigm of modern international law" in HP Hestermeyer, D König, N Matz-Lück, V Röben, A Seibert-Fohr, PT Stoll \& S Vöneki (eds) Coexistence, cooperation and solidarity: Liber Amicorum Rüdiger Wolfrum $(2012) \mid 4$.

223 J Delbrück "The international obligation to cooperate - An empty shell or a hard law principle of international law? - A critical look at a much debated paradigm of modern international law" in HP Hestermeyer, D König, N Matz-Lück, V Röben, A Seibert-Fohr, PT Stoll \& S Vöneki (eds) Coexistence, cooperation and solidarity: Liber Amicorum Rüdiger Wolfrum (20I2) I4.

${ }^{224}$ EA Stanton "The tragedy of maldistribution: Climate, sustainability, and equity" (2012) 4 Sustainability 407.

${ }^{225} \mathrm{HP}$ Hestermeyer "Reality or aspiration? - Solidarity in international environmental and world trade law" in HP Hestermeyer, D König, N Matz-Lück, V Röben, A Seibert-Fohr, PT Stoll \& S Vöneki (eds) Coexistence, cooperation and solidarity: Liber Amicorum Rüdiger Wolfrum (2012) 48.

226 UNGA Res. 55/2 para. 6 (adopted without vote).

${ }^{227}$ United Nations Conference on Environment and Development, Rio Declaration on

Environment and Development (14-07-1992) 31 ILM 874.

${ }^{228} \mathrm{R}$ Wolfrum Die Internationalisierung staatsfreier Räume (1984).

${ }^{229}$ HP Hestermeyer "Reality or aspiration? - Solidarity in international environmental and world trade law" in HP Hestermeyer, D König, N Matz-Lück, V Röben, A Seibert-Fohr, PT Stoll \& S 
Vöneki (eds) Coexistence, cooperation and solidarity: Liber Amicorum Rüdiger Wolfrum (2012) 63.

230 A Seibert-Fohr "The international covenant on civil and political rights: Moving from coexistence to cooperation and solidarity" in HP Hestermeyer, D König, N Matz-Lück, V Röben, A Seibert-Fohr, PT Stoll \& S Vöneki (eds) Coexistence, cooperation and solidarity: Liber Amicorum Rüdiger Wolfrum (20 I2) 517-552.

${ }^{231}$ R Wolfrum "Solidarity amongst states: An emerging structural principle of international law" in F Piovesan \& IV Prado Soares (eds) Direito ao Desinvo/vimento (20 I0) 57-72.

232 J Mathiason \& MP Bhandari "Getting the facts right: The Intergovernmental Panel on Climate Change and the new climate regime" (20 I0) I:I Journal of International Organization Studies $57-71$.

${ }^{233}$ W Steffen, RA Sanderson, PD Tyson, J Jäger, PA Matson, B Moore, F Oldfield, K Richardson, HJ Schellnhuber, BL Turner \& RJ Wasson Global change and the Earth system (2004); HJ Schellnhuber, PJ Crutzen, WC Clark, M Claussen \& H Held (eds) Earth system analysis for sustainability (2004).

${ }^{234}$ J Rockström, W Steffen, K Noone, Lambin, TM Lenton, M Scheffer, C Folke, HJ Schellnhuber, B Nykvist, CA de Wit, T Hughes, S van der Leeuw, H Rodhe, S Sörlin, PK Snyder, R Costanza, U Svedin, M Falkenmark, L Karlberg, RW Corell, VJ Fabry, J Hansen, B Walker, D Liverman, K Richardson, P Crutzen \& JA Foley "A safe operating space for humanity" (2009) Nature 472475.

${ }^{235}$ F Biermann, K Abbott, S Andresen, K Bäckstrand, S Bernstein, MM Betsill, H Bulkeley, B Cashore, J Clapp, C Folke, A Gupta, J Gupta, PM Haas, A Jordan, N Kanie, T KluvánkováOravská, L Lebel, D Liverman, J Meadowcroft, RB Mitchell, P Newell, S Oberthür, L Olsson, P Pattberg, R Sánchez-Rodríguez, H Schroeder, A Underdal, S Camargo Vieira, C Vogel, OR Young, A Brock \& R Zondervan "Navigating the Anthropocene: Improving earth system governance" (20I2) 335:6074 Science I306-I307.

${ }_{236}$ UN Secretary-General Ban Ki-moon's remarks at the Sorensen Distinguished Lecture on the United Nations at the Council on Foreign Relations, New York ( I I-02-20 I3) http://www.un.org/sg/statements/index.asp?nid=6595 (accessed 17-02-20 I3).

${ }^{237}$ RO Keohane \& DG Victor "The regime complex for climate change" (20I I) 9:1

Perspectives on Politics 7-23.

238 TW Pogge "International relations as a modus vivendi" (1987) 81 American Proceedings of International Law 426.

239 TW Pogge "International relations as a modus vivendi" (1987) 81 American Proceedings of International Law 427.

${ }^{240}$ S Hockman "The case for an international court for the environment" (2010) 3:I Journal of Court Innovation 215.

${ }^{241}$ C Tomuschat "Risk and security in international law" in HP Hestermeyer, D König, N MatzLück, V Röben, A Seibert-Fohr, PT Stoll \& S Vöneki (eds) Coexistence, cooperation and solidarity: Liber Amicorum Rüdiger Wolfrum (20 I2) 1285.

${ }^{242}$ C Tomuschat "Risk and security in international law" in HP Hestermeyer, D König, N MatzLück, V Röben, A Seibert-Fohr, PT Stoll \& S Vöneki (eds) Coexistence, cooperation and solidarity: Liber Amicorum Rüdiger Wolfrum (20 I2) 1285. 